\title{
MÜSADERE KARARI BAKIMINDAN CEBRİ İCRA İŞLEMLERİ
}

THE MEASURES OF THE COMPULSORY ENFORCEMENT PROCEEDING

IN RESPECT OF THE CONFISCATION ORDER

Hakemli Makale

Taner Emre YARDIMCI*

\section{IÇİNDEKILER}

GíRiş 366

I- MÜSADERE KARARININ İCRA TAKIP İșLEMLERI İLE OLAN İLIŞKISIININ BELIRLENMESI 367

A- Müsadereye Konu Olabilecek Malvarlı̆̆ı Değerleri ve Müsaderenin Hüküm ve Sonuçlarını

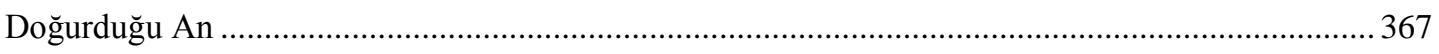

1- Müsadereye Konu Olabilecek Malvarlı̆ğ Değerleri ................................................................... 367

2- Müsadere Kararı Verilmesine Getirilen Sinırlamalar ............................................................. 370

3- Müsadereye Karar Verilmesi ve Müsadere Kararının Hüküm ve Sonuçlarını Doğurduğu An. 374

B- İcra Takibine Konu Malvarlığı Değeri Hakkında Müsadere Kararı Verilmesi ................................ 377

C- Haczedilmiş Malvarlı̆ğ Değeri Hakkında Müsadere Kararı Verilmesi ........................................... 380

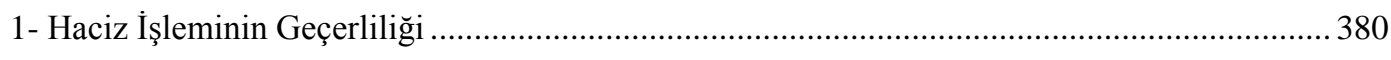

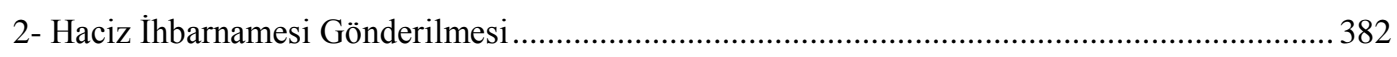

II- MÜSADEREYE KARAR VERILMESI VE İCRA TAKİ İșLEMLERININ YAPILMASI......................................... 384

A- Müsadereye Karar Verme Sürecinde İcra Takip İşlemlerinin Yapılmas1 ........................................ 384

1- Hacizde Tertip İlkesi Gereği Elkoyma Kararının Dikkate Alınması ..........................................384

2- Elkoyma Kararı ve Takibin İlerlemesine Yönelik İşlemlerin Gerçekleştirilmesi ....................... 386

B- Müsadere Kararına Rağmen Takip İşlemlerinin Yapılması ve Takip Bittikten Sonra Müsadereye

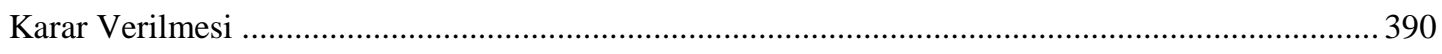

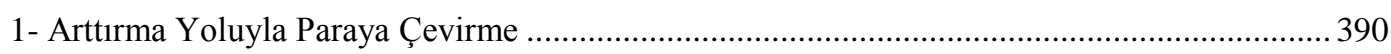

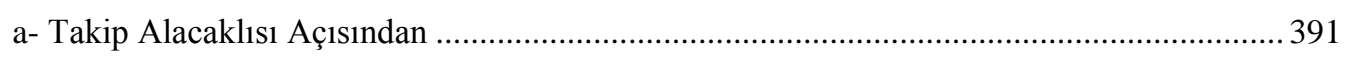

b- Cebri Satışa İştirak Etmiş Alıcı Açısından .............................................................................. 393

aa- İhale Tarihinden İtibaren Yedi Günlük Sürede İhalenin İptali ......................................... 393

bb- Öğrenmeden İtibaren Yedi Günlük Sürede İhalenin İptali ................................................... 396

cc- İhalenin İptalini İsteme Sürelerinin Geçmiş Olması ............................................................ 397

DOI: $10.32957 /$ hacettepehdf.599234

Makalenin Geliş Tarihi: 03.08.2019

Makalenin Kabul Tarihi: 22.10.2019

* Dr. Öğretim Üyesi. Atatürk Üniversitesi Hukuk Fakültesi Medeni Usul ve İcra-İflas Hukuku Anabilim Dalı Ögretim Üyesi. E-posta: t.e.yardimci@gmail.com

ORCID: 0000-0002-5330-4986 
2- Pazarlık Yoluyla Paraya Çevirme. 399

III- MÜSADERE KONU MALVARLIĞININ BEDELININ TAHSIL EDILLMESI.

A- Başka Takip Alacaklarına Ödeme Yapma Gerekliliği. 401

B- Müsadere Bedelinin Tahsilinde İzlenecek Usul....

SONUÇ

KAYNAKÇA 408

\title{
ÖZ
}

Bir suçun işlenmesinde kullanılan veya bir suçun işlenmesine tahsis edilen veyahut bir suçtan meydana gelen eşyalar ile bir suçtan elde edilen kazançlar müsadere edilir. Borçlu aleyhine olan müsadere kararı derdest bir icra takibini iki şekilde ilgilendirebilir. İlk olarak mahkeme, önceden haczedilmiş veya haczedilecek bir eşyanın veya kazancın müsadere edilmesi kararı verilebilir. İkinci olarak, bizzat icra takibinin konusu olan bir eşya hakkında müsadereye hüküm kurulmuş olabilir. Bu gibi durumlarda, takip alacaklısı ile devletin menfaatleri arasında bir çatışma doğar. Müsadere kararının hukuki etkisini doğurduğu an, hangi menfaatin tercih edileceğinde belirleyici olur. Müsadere kararının kesinleşmesi ile birlikte, müsadere edilen eşyanın veya kazancın mülkiyeti devlete geçer. Bundan sonra, bu nitelikteki bir eşya veya kazanç haczedilemez ve cebri icra yoluyla satılamaz. Şu var ki, müsadere kararı kesinleşmeden önce gerçekleşmiş icra takip işlemleri (Ör. borçlunun bir eşyasının haczi), müsadere kararına rağmen geçerliliğini korumalıdır.

Anahtar Kelimeler: Müsadere, eşya, kazanç, icra takibi, haciz, cebri satımın iptali.

\begin{abstract}
The assets that used or allocated to commit a crime or come into the existence from a crime and the financial benefits obtained from a crime should be confiscated. A confiscation order against a debtor could concern the pending enforcement proceeding in two ways. In the first instance, the court may order to confiscate an asset or financial benefit which are already attached or will be attached. Secondly, the confiscation order may be given on an asset which is itself content of an enforcement proceeding. In such cases, there will be a conflict between the interests of the creditor and the state. The time on which the legal effect of a confiscation order takes place will be decisive at the preference of these interests. With the finalization of a confiscation order, the ownership of the confiscated asset or financial benefit will pass into the state. Hereafter, such an asset or financial benefit could not be attached and sold by compulsory tender. The fact remains that the enforcement measures (e.g. attachment of an asset of the debtor) which took place before the finalization of the confiscation order should have their legal effect despite the confiscation order.
\end{abstract}


Key words: Confiscation, asset, financial benefit, enforcement proceeding, attachment, annulment of the compulsory tender.

\section{GíRiş}

Hakkında müsadere kararı verilen belirli bir malvarlığı değerinin mülkiyeti devlete geçer. Bu durum sebebiyle, müsadere konusunda genellikle malik olan kişinin mülkiyet hakkının ihlal edilip edilmediği üzerinde durulmaktadır. Oysa suçla mücadele amac1yla uygulanan müsadere kararının mülkiyet hakkı ile olan bu doğrudan ilişkisi, icra takip işlemlerini de etkileyebilir. Çünkü aleyhine müsadere kararı verilen bu kişiden alacaklı olanların alacak hakları da müsadere kararına bağlı hâle gelir. Bu yüzden, alacak haklarına müdahale edilme ihtimali olan icra takibine göre alacaklı olan kişiler açısından da müsadere kararı ele alınmalıdır.

Müsadere kararının yöneldiği malvarlığı değeri iki şekilde icra takip işlemlerini ilgilendirebilir. İlk hâl, müsadere kararının muhatabı olan kişinin buna konu malvarlığı değerinin haczedilmesinde ortaya çıkar. Aynı malvarlığı bakımından müsadereye karar verilirse, haciz ve satış işlemlerine ne şekilde devam edileceği belirlenmelidir. İkinci hâl ise takibe konu olan malvarlığı hakkında müsadere kararı verilmesinde söz konusu olur. Söz gelimi, rehin hakkı sahibi tarafından rehnin paraya çevrilmesi yoluyla takip başlatılmış iken, rehinli malvarlığı hakkında müsadere kararı verilir ve bu karar kesinleşirse, sadece rehin hakkının geçerli kalması kaydıyla icra takip işlemlerine devam edilebilir. Başka bir misal ise ilama dayalı takipte teslimi gereken taşınır veya taşınmazın müsadere edilmesi olabilir. Gerek hacizli malvarlığı değerinin gerekse takip konusu malvarlığının müsadere edilmesinde, bu kararın hukuki niteliği ve amacı dikkate alınarak bir sonuca varılmalidir.

İcra takibi neticesinde müsadere kararının icrası mümkün olmazsa, eşdeğer müsaderesi gündeme gelir. Eşdeğer müsaderesinde devlet, müsadere konusu şeyin parasal değeri kadar aleyhine müsadere kararı verilen kişiden alacaklı hâle gelir. Bu alacağın tahsilinde ise cebri icra yoluyla takip yapılmalıdır. Suç Eşyası Yön. m. 18/1 - (e)'de bu icra takibinin 6183 sayılı K. hükümlerine göre gerçekleşebileceği öngörülmüştür. Takip 
usul ve esaslarının kanunilik ilkesine tabi olması noktasında bu düzenlemeye binaen 6183 sayılı K. hükümlerinin uygulanmasının mümkün olup olmadığı ele alınmalıdır.

\section{I- Müsadere Kararının İcra Takip İşlemleri ile Olan İlişkisinin Belirlenmesi}

Hukuki niteliği tartışmalı olmakla birlikte 5237 sayılı Türk Ceza Kanunu (TCK) sistematiğinde bulunduğu yer itibariyle müsadere, bir güvenlik tedbiridir ${ }^{1}$. Müsadere, suç ile doğrudan ilgili olan bir malvarlığı değerinin (eşya veya kazanç) mülkiyetinin devlete geçmesi sonucunu doğuran bir kurumdur. Mülkiyetin devlete geçmesi durumu müsaderenin en tipik özelliğidir. Müsadereye karar verilmesindeki amaç, genel olarak gerçekleşmiş eylemin bir sonucu olarak ortaya çıkmış tehlikeliliğ $\mathrm{e}^{2}$ göre hem ilgili kişi aleyhine bir yaptırım uygulanması hem toplumun korunmasıdır. İcra takibinde de takip borçlusunun mülkiyet hakkı başkasına geçebilmektedir. Mülkiyet hakkına yönelik bu hukuki sonuçlar, müsadere kararının uygulanmasında ve icra takip işlemlerinin yapılmasında, hangisine öncelik tanınması gerektiği sorusunu da beraberinde getirmektedir.

\section{A- Müsadereye Konu Olabilecek Malvarlığı Değerleri ve Müsaderenin} Hüküm ve Sonuçlarını Doğurduğu An

İcra takibi bakımından müsadere kararının ele alınabilmesi için öncelikle müsaderenin hangi malvarlığ 1 değerleri hakkında gerçekleşeceği belirlenmelidir. Bundan başka, müsadere kararının hüküm ve sonuçlarını doğurduğu tarih de önemlidir.

\section{1- Müsadereye Konu Olabilecek Malvarlığı Değerleri}

Suçun işlenmesinde bir şekilde yararlanılan bir eşya veya suçtan elde edilen bir kazanç hakkında müsadere kararı verilebilir. İlk hâl için “eşya müsaderesi”; ikinci hâl

1 AKBUluT, Berrin, Ceza Hukuku (Genel Hükümler), 5. Bası, Seçkin Yayınevi, Ankara, 2018, s. 873; GÖKCEN, Ahmet/BALCI, Murat/ALŞAHIN, Emin/ÇAKIR, Kerim, Ceza Muhakemesi Hukuku, 3. Bası, Seçkin Yayınevi, Ankara, 2018, s. 900. Aleyhe bozma yasağı açısından verdiği bir kararda Yargıtay, müsadereyi güvenlik tedbiri olarak nitelendirmiştir, bkz. Yargıtay CGK, E. 2011/6-219, K. 2011/280, T. 20.12.2011 (Kazancı Bilişim - İçtihat Bilgi Bankası, Erişim Tarihi: 03/02/2019).

2 Müsadere konusu şeyin arz ettiği tehlikelilik dikkate alınarak müsadere kararı verilmektedir, bkz. GÜNGÖR, Devrim/TOROSLU, Haluk, "Müsadere ve Hükmün Açıklanmasının Geri Bırakılması İlişkisi Üzerine Kısa Bir Değerlendirme”, Ankara Üniversitesi Hukuk Fakültesi Dergisi, Y1l: 2016, Cilt: LXV, Sayı: 4, s. 1969; GEDİK, Doğan, 5237 sayılı Türk Ceza Kanunu ve 5271 sayılı Ceza Muhakemesi Kanunu’na Göre Müsadere, 2. Bası, Adalet Yayınevi, Ankara, 2016, s. 102, 103. 
için ise "kazanç müsaderesi" tabirleri kullanılmaktadır'. Gerek eşya müsaderesinde gerekse kazanç müsaderesinde müsadere kararı konusuz kalabilir. Diğer bir ifadeyle, müsadere kararının icrası, bazı hâllerde fiilen mümkün olmayabilir. Böyle bir durumda, eşya müsaderesi hakkında TCK (Türk Ceza Kanunu) m. 54/2 hükmüne göre; kazanç müsaderesi hakkında ise TCK m. 55/2'ye göre eşdeğer müsaderesi gündeme gelir ${ }^{4}$. Eşdeğer müsaderesinin uygulandığı hâllerde, aleyhine müsadere kararı verilmiş kişiden belirli bir parasal değerin tahsili yoluna gidilir.

Eşya müsaderesinin hangi hâllerde söz konusu olabileceği, TCK m. 54/1, 1. cümlede ifade edilmiştir. Bir suç işlenmesinde kullanılan veya suçun işlenmesine tahsis edilen veyahut suçtan meydana gelen eşya müsadere edilmelidir. Bunun yanı sıra, TCK m. 54/1, 2. cümlede özel bir durumdan daha bahsedilmiştir. Buna göre, suçun işlenmesinde kullanılmak üzere hazırlanan bir eşya dahi müsadere edilebilmektedir. Eşyanın bu kapsamda müsadere edilmesi ise kamu güvenliği, kamu sağlığı veya genel ahlak açısından tehlikeli olması şartına bağlanmıştır. Yine eşya müsaderesi kapsamında TCK m. 54/4'te ifade edildiği üzere üretimi, bulundurulması, kullanılması, taşınması, alım ve satımı suç oluşturan eşya da müsadere edilebilmektedir. Hatta bu malvarlığı değerlerinin sırf mevcut olması, müsadereye karar verilmesini haklı k1lmaktadır 5 . Çünkü müsadere kararı verilmediği takdirde, bunların yine başka suçlarda kullanılması mümkündür ${ }^{6}$. Esasen TCK m. 54/1, 2. cümlenin ve 54/4'ün kapsamına giren eşyaların (bandrolsüz alkollü içecek ve tütünler, kanuna aykırl yollarla edinilen araç motorlarl, ruhsatsı silah vb.) icra takip işlemleri açısından değerlendirilmesine gerek de yoktur. Bu nitelikteki bir eşya hakkında haciz uygulanmaz. Diğer taraftan, bir davada bu nitelikteki bir eşyanın

3 CENTEL, Nur/ZAFER, Hamide/ÇAKMUT, Özlem, Türk Ceza Hukukuna Giriş, 10. Bası, Beta Yayınevi, İstanbul, 2017, s. 736-738.

4 Öğretide müsadere imkânı kalmaması sebebiyle aynı değerdeki parasal değerin talep edilmesi, eşya ve kazanç müsaderesi için sırasıyla "eşdeğer müsaderesi" ve "kaim değer müsaderesi" kavramları ile ifade edilmektedir. Her iki hâlde de farklı kavramların kullanılması isabetli görülmemektedir, bkz. SOYGÜT-ARSLAN, Mualla Buket, Türk Ceza Hukukunda Müsadere, Yayımlanmamış Doktora Tezi, İstanbul, Galatasaray Üniversitesi Sosyal Bilimler Enstitüsü, 2014, s. 448-450. Kanaatimizce de farklı kavramların kullanılmasına lüzum olmadığından, bu çalışmada "eşdeğer müsaderesi” kavramının kullanılması tercih edilmiştir.

5 GÜNGÖR/TOROSLU, 2016, s. 1974; AKBULUT, 2018, s. 877, 878.

6 SOYGÜT-ARSLAN, 2014, s. 36. 
bir taraftan alınıp diğer tarafa verilmesi yönünde hüküm kurulamayacağı için bunlar hakkında ilamlı icra takibi yapılması da düşünülemez.

Suç işlerken bir şekilde yararlanılan bir eşya hakkındaki müsadere kararı ise derdest icra takibini etkileyebilir. Suçun işlenmesini kolaylaştıran bir eşya bile müsadereye konu olabilir ${ }^{7}$. Bu noktada, eşyanın haczedilmesinin mümkün olup olmadığı veyahut haczedilmişse haczin kalkmasının gerekip gerekmediği soruları doğar. Çünkü satış işlemlerinin gerçekleşmesi, geçerli bir haczin varlığına bağlıdır ${ }^{8}$. Ayrıca, eşyanın borçludan alınıp takip alacaklısına verilmesi (ilamlı icra takibinde) veya rehinli olan bu eşyanın paraya çevrilmesinin ne şekilde olacağının belirlenmesi ihtiyacı doğar.

TCK m. 55 hükmü gereğince, suçtan elde edilen veya suçun konusunu oluşturan veyahut suçun işlenmesi için sağlanan maddi menfaatler ile bunların değerlendirilmesi veya dönüştürülmesi sonucu ortaya çıkan ekonomik kazançlar ise kazanç müsaderesi kapsamında müsadere edilir. Elde edilen kazanç ile farklı bir malvarlığı değeri iktisap edilirse, bu malvarlığı değeri hakkında da müsadere kararı verilebilir ${ }^{9}$. Kazanç müsaderesine karar verilebilmesi için kazanç ile işlenen suç arasında mutlaka bir bağ olmalıdir ${ }^{10}$. Suçun mağduruna ait olan bir malvarlığı değerinin kazanç müsaderesine konu olması ise mümkün değildir ${ }^{11}$. Bu hâlde, CMK (Ceza Muhakemesi Kanunu) m. 256/2

7 CENTEL/ZAFER/ÇAKMUT, 2017, s. 741.

8 ARSLAN, Ramazan, İcra-İflâs Hukukunda İhale ve İhalenin Feshi, Ankara Üniversitesi Hukuk Fakültesi Yayınları, Ankara, 1984, s. 77; KURU Baki, İcra ve İflas Hukuku (El Kitabı), 2. Bası, Adalet Yayınevi, Ankara, 2013, s. 702.

9 GÜNLER, Kemal, “Türk Ceza Hukukunda Müsadere”, Gazi Üniversitesi Hukuk Fakültesi Dergisi, Y1l: 2014, C. XVIII, Say1: 3-4, s. 868; ARTUK, Mehmet Emin/GÖKÇEN, Ahmet/YENIDÜNYA, Caner/ÇAKIR, Kerim, Ceza Hukuku (Genel Hükümler), 12. Bası, Adalet Yayınevi, Ankara, 2018, s. 908.

10 SOYGÜT-ARSLAN, 2014, s. 460, 461; ARTUK/GÖKÇEN/YENIDÜNYA/ÇAKIR, 2018, s. 907.

11 GÜNLER, 2014, s. 868; ZAFER, Hamide, Ceza Hukuku Genel Hükümler (TCK m. 1-75), 6. Bas1, Beta Yayınevi, İstanbul, 2016, s. 644; ÖZGENÇ, İzzet, Türk Ceza Hukuku, 14. Bası, Seçkin Yayınevi, Ankara, 2018, s. 853. Yargitay 6. CD, E. 2008/9505, K. 2009/13227, T. 13.10.2009 (Kazanc1 Bilişim - İçtihat Bilgi Bankası, Erişim Tarihi: 03/02/2019): "Yağma suçundan sanık hakkında; müsadere kararı verilebilmesi için maddi menfaatin suçun mağduruna iade edilmemesi gerekir. Suçun mağdurunun, kazanç müsaderesinin konusunu oluşturan değeri, sanıktan talep etme hak ve olanağına sahip olduğu, yakınanı belli olan ve yağma suçunun konusunu oluşturan paranın toplam tutarının özel hukuk davası yoluyla talep edilebileceğinin gözetilmeden, kazanç müsaderesine karar verilmesi yasaya aykırıdır.”. Aynı yönde olan başka bir karar için bkz. Yargıtay 17. CD, E. 2015/23751, K. 2017/13748, T. 13.11.2017 (Kazancı Bilişim - İçtihat Bilgi Bankası, Erişim Tarihi: 03/02/2019). 
gereğince iade edilmesi gereken bir malvarlığı söz konusu olup; resen veya ilgilinin istemi üzerine iadeye karar verilmelidir ${ }^{12}$.

Kazanç müsaderesinde müsadere kararı, hiç şüphesiz ki icra takibini de ilgilendirebilir. Haciz esnasında para gibi bir malvarlığı değeri bakımından İ̇K (İcra ve İflas Kanunu) m. 85 düzenlemesine göre hacizde tertip ilkesi gereğince öncelikle bu ekonomik değerin haczedilmesi yoluna gidilmelidir. Dolayısıyla, kazanç müsaderesine konu olabilecek malvarlığı değeri (çoğunlukla para olacağından dolayı) icra takibinin öncelikle yöneleceği bir değerdir. Görülüyor ki, kazanç müsaderesine konu olabilecek malvarlığı hakkında uygulanacak haciz işleminin düşmesinin gerekip gerekmediği sorunu ile çoğunlukla karşılaşılabilir.

\section{2- Müsadere Kararı Verilmesine Getirilen Sınırlamalar}

Müsaderenin her iki türünde de asıl amaç, belirli bir malvarlığı değerinin mülkiyetini devlete geçirmek değildir. Amaç ne olursa olsun mülkiyetin devlete geçmesi yönündeki bu yaptırım, failin mülkiyetinde olan bir malvarlığı hakkında gerçekleşir. Nitekim TCK m. 54/1'de iyiniyetli üçüncü kişiye ait olan bir eşyanın müsadere edilemeyeceği vurgulanmıştır. Yine aynı hükümde sınırlı ayni hakları etkileyecek şekilde müsadere kararı verilemeyeceği öngörülmüştür. Suçtan haberdar olup olmama durumu ise TCK m. 54'te "iyiniyet" kavramı ile ifade edilmiştir ${ }^{13}$. Şayet üçüncü bir kişiye ait bir mal ve hak varsa ve o kişi iyiniyetli ise bu mal ve hak bakımından müsadere kararı verilemez ${ }^{14}$.

Diğer bir sınırlandırma ise TCK m. 55/3’te kazanç müsaderesi bakımından bunu iktisap eden üçüncü kişi için öngörülmüştür. Bu hükmün eşya müsaderesi hakkında da

12 İlgili kişi (aleyhine müsadere kararı verilmesi ihtimali olan) bakımından fiilen bir kazanç söz konusu olmadığı için mağdura iade edilen kısım yönünden müsadere kararı verilmemelidir, bkz. GEDİK, 2016, s. 229, 230.

13 CENTEL/ZAFER/ÇAKMUT, 2017, s. 742.

14 AKBULUT, 2018, s. 877; ÖZTÜRK, Bahri/ERDEM, Mustafa Ruhan, Uygulamalı Ceza Hukuku ve Güvenlik Tedbirleri Hukuku, 18. Bası, Seçkin Yayınevi, Ankara, 2018, s. 545. TCK (Türk Ceza Kanunu) m. 54'ün gerekçesinde bu durum şu şekilde ifade edilmiştir: “... kişinin suçun işlenmesine iştirak etmemesi, suçun işlenişinden haberdar olmaması durumunda, sahibi bulunduğu eşya bir suçun işlenmesinde kullanılmış bile olsa, müsadereye hükmedilmeyecektir. ...". 
uygulanması mümkündür ${ }^{15}$. Müsadere edilme ihtimali olan veya müsadere edilmiş bir malvarlığı değerini iyiniyet kurallarına göre iktisap eden kişinin aleyhine olacak şekilde müsadere işlemi uygulanmaz ${ }^{16}$. Mesela, elde edilmiş kazanç ile bir borç ödenmişse, TCK m. 55/3 hükmü bu durumda uygulanır ve buna göre ödeme işlemi geçerli olur ${ }^{17}$. Kendisine ödeme yapılmış iyiniyetli üçüncü kişiden bu bedel müsadere kararıyla geri alınmamalıdır. Ancak, aleyhine müsadere kararı verilen kişi bakımından ise bir zenginleşme meydana geldiği göz ardı edilemez. İşte, müsadereye konu olamayan bu kısım için eşdeğer müsaderesi gerçekleşmektedir ${ }^{18}$. Dolayısıyla, üçüncü kişi aleyhine müsadere kararı verilemese de üçüncü kişinin iyiniyeti sebebiyle elde edilemeyen kısım için eşdeğer müsaderesi mümkün olmalıdır.

Bazı hâllerde ise müsadereye karar verilirken mülkiyetin kime ait olduğunu belirlemek kolay olmayabilir. Sicile kayıtlı malvarlığ değerleri bakımından özellikle böyle bir durum yaşanabilir. Kayda göre aleyhine müsadere kararı verilecek kişinin malik olarak gözükmesine rağmen, gerçekte üçüncü bir kişinin mülkiyetinde bulunan bir malvarlığı değeri hiçbir şekilde müsadereye tabi tutulmamalıdır. Mesela, sicile kayıtlı olan

15 Aynı kuralın eşya müsaderesi için de geçerli olduğu belirtilmiştir, bkz. ZAFER, 2016, s. 642. Buna göre, eşya müsaderesinde de müsadereye konu malvarlığı değerini iyiniyetli olarak iktisap eden üçüncü kişinin iktisabı korunmalıdır.

16 Suç işlendikten sonra müsadereye konu olacak şeyi iktisap eden iyiniyetli üçüncü kişi aleyhine de sonuç doğuracak şekilde müsadere kararı verilmesi doğru değildir. Şu hâlde, TCK m. 55/3 hükmünün sonradan eklenmesi olumlu karşılanmıştır, bkz. ÖZGENÇ, 2018, s. 855. ACK (Alman Ceza Kanunu) m. 75/3'te iyiniyet kurallarına istinaden müsadere konusu malvarlığının iktisap edilmesi hâlinde, üçüncü kişi aleyhine sonuç doğuracak şekilde müsadere kararı verilemeyeceği kabul edilmiştir. Burada AMK (Alman Medeni Kanunu) m. 136'ya göre bir değerlendirme yapılmaktadır. Eğer üçüncü kişi iyiniyetli ise AMK m. 135'e göre yapılan devrin geçerli görülmesi mümkündür. Buna karşın, malvarlığı değerinin müsaderesi sırf bu değerin varlığından ileri geliyorsa, AMK m. 134 uygulanmalı ve devir işlemi her hâlükârda geçersiz görülmelidir, bkz. Heuchemer: Beck'scher Online-Kommentar zum Strafgesetzbuch (Hrsg.: von Heintschel-Heinegg, Bernd), 34. Ed., München, 2017 (BeckOK StGB), § 75 kn. 4.

17 Kazanç müsaderesinin konusu taşınır veya taşınmaz bir mal da olabilir. Mevzuatta iyiniyetli olma hakkındaki şartlar (iktisap anında veya belirli bir süre içinde iyiniyetli olmak gibi) sağlandığı takdirde, CMK (Ceza Muhakemesi Kanunu) m. 55/3 gereğince yine müsadereye karar verilememelidir.

18 SOYGÜT-ARSLAN, 2014, s. 458. Almanya'da ise ACK m. 73c, 2. cümlede aynı yönde bir düzenlemeye yer verilmiştir. İlk başta edinilen malvarlığında meydana gelen azalma eşdeğer müsaderesine karar verilmesini haklı kılar. Eşdeğer müsaderesinin miktarı ise ilk baştaki değer ile sonraki değer arasindaki farktır, bkz. Heuchemer: Beck'scher Online-Kommentar zum Strafgesetzbuch (Hrsg.: von Heintschel-Heinegg, Bernd), 34. Ed., München, 2017 (BeckOK StGB), § 73c kn. 8. Türk hukukunda söz gelimi uyuşturucu madde ticaretinden elde edilen gelirin harcanması hâlinde, harcanmış kısım için müsadere kararı verilemeyeceği görüşü de savunulmaktadır, bkz. ARTUK/GÖKÇEN/YENIDÜNYA/ÇAKIR, 2018, s. 907, 908. 
bir aracın satışı noter önünde yapılmışsa, trafik sicilinde gerekli değişiklikler gerçekleşmese bile, KTK (Karayolları Trafik Kanunu) m. 20/1 - (d) hükmünce devir gerçekleşmiş olur ${ }^{19}$. Sicil kaydının değiştirilmesi ihmal edilirse, aleyhine müsadere kararı verilecek kişiye ait bir aracın olduğu düşünülebilir. Hatta araç hakkında müsaderenin uygulanabilmesi adına elkoyma kararı dahi verilmiş olabilir. Bu hâlde, mülkiyetin üçüncü kişiye geçmesi için tescil işleminin kurucu olmadığına dikkat edilmelidir. Her ne kadar sicil kaydı aleyhine müsadere kararı verilmesi gereken kişinin hak sahibi olduğu yönünde de olsa, müsadereye karar verilmemelidir ${ }^{20}$. Doğal olarak, müsaderenin uygulanmasının sağlanması amacıyla elkoyma kararının verilmesi de hatalı olur. Benzer bir durumda, icra takibi kapsamında aracın haczinin de mümkün olmayacağını söyleyebiliriz. Mülkiyeti üçüncü kişiye ait olan böyle bir eşya hakkında istihkak davasında ilişkin İİK (İcra ve İflâs Kanunu) m. 96 vd. hükümlerine göre hacze itiraz edilebilir ${ }^{21}$. O hâlde, noterlikte devir işlemi yapılmamışsa (haricen gerçekleşen satımlarda), sicil kaydında aracın maliki gözüken kişi açısından müsadere ve haciz işlemlerinden hangisine öncelik verilmesi gerektiği değerlendirmesi yapılabilir.

Mülkiyeti saklı tutma kaydıyla yapılan satımlarda da malikin kim olduğunun belirlenmesi gerekir. Bu tür satımlarda alıcı tarafın öngörülmüş bedelin tamamını ödemesi ile birlikte mülkiyet alıcıya geçer ${ }^{22}$. Bedelin tamamının ödenip ödenmemesine (gecikti-

19 Sicile hiç kayıt edilmemiş bir aracın devrinde ise herhangi bir şekil şartı öngörülmemiştir. Bu nitelikteki bir araç hakkında müsadere kararı verilirken TMK (Türk Medeni Kanunu) m. 763/1'e başvurulmalıdır. Hükme göre, aracın zilyetliği devredildiğinde mülkiyetin de karşı tarafa geçmesi söz konusudur. Demek ki, zilyetliğin geçme anına göre aracın malikinin kim olduğu belirlenmelidir.

20 ALtUĞ, Şahin, Ceza Hukukunda Müsadere Kavramı, Adalet Yayınevi, Ankara, 2017, s. 168; GEDİK, 2016, s. 176.

21 Yargıtay 17. HD, E. 2011/2998 K. 2011/7486 T. 14.7.2011 (Kazancı Bilişim - İçtihat Bilgi Bankası, Erişim Tarihi: 03/02/2019). Öğretide diğer kanunlarda düzenlenmiş istihkak davalarından İ̇K m. 96 vd. hükümlerinden düzenlenen istihkak davasının farkını belirtmek üzere "hacze itiraz (muhalefet) davası" kavramının kullanılmasının daha isabetli olduğu belirtilmektedir, bkz. ASLAN, Kudret, Hacizde İstihkak Davası, Turhan Yayınevi, Ankara, 2005, s. 19, 20. Nitekim İIK m. 96 vd. hükümlerine göre yapılan istihkak iddiasında belirli bir malvarlığının hacizden kurtarılması için bu yola başvurulmaktadır, bkz. KURU, 2013, s. 542. Söz konusu öneriyi yerinde görmemiz sebebiyle, çalışmamızda "hacze itiraz edilmesi" veya "hacze itiraz davası" ifadeleri kullanılmaya çalışılmıştır.

22 Mülkiyeti saklı tutma sözleşmeleri hakkında TMK m. 764'te şöyle bir hüküm yer almaktadır: "Başkasına devredilen bir malın mülkiyetinin saklı tutulması kaydı, ancak resmi şekilde yapılacak sözleşmenin devralanın yerleşim yeri noterliğinde özel siciline kaydedilmesiyle geçerli olur.”. Buna göre, özel sicile kaydedilmediği takdirde, kesin satış sözleşmesinin varlığı kabul edilmelidir, bkz. Yargitay 21. HD, E. 2003/14, K. 2003/1028, T. 18.02.2003 (Kazanc1 Bilişim - İçtihat Bilgi Bankası, Erişim Tarihi: 
rici şartın gerçekleşip gerçekleşmemesine) ${ }^{23}$ göre, eşyanın müsadere edilip edilemeyeceği belirlenmelidir. Mülkiyetin satıcıya ait olduğu aşamada, satıcı taraf, TCK m. 54/1 anlamında "iyiniyetli" ise aracın müsaderesine karar verilemez ${ }^{24}$. Satım sözleşmesine göre geri kalan kısım sonradan satıcıya ödense bile müsadere kararı verilmemelidir. Zira müsadereyi haklı kılan sebeplerin gerçekleştiği tarihte alıcı taraf henüz malik değildir. Yalnızca ödemenin tamamen yapıldığg anda alıcı taraf malik hâline gelmektedir. Suçun işlendiği ana kadar alıcının satıcıya ödemiş olduğu bedelin müsadereye tabi olup olmadığı da değerlendirilebilir. TCK m. 54/1, 1. cümleye göre, satıcıya ödenmiş bedelin kasıtlı bir suçun işlenmesinde kullanılan veya suçun işlenmesine tahsis edilen ya da suçtan meydana gelen eşya olarak görülmesi mümkün olmadığı için müsadere edilmemesi gerekir. Her ne kadar çeşitli ihtimallere göre satılan malın veya satıcıya ödenen bedelin haczi mümkün ${ }^{25}$ de olsa, sözü geçen malvarlığı değerleri hakkında müsadere karar1 verilmemelidir.

Finansal kiralamaya konu malvarlığı değerlerinin de müsadere kararına konu olması mümkündür. Öncelikle belirtmek gerekir ki, kiracının eylemleri sebebiyle müsadereye karar verilmesi, kiraya verenin iyiniyetli olması hâlinde TCK m. 54/1 hükmü gereği mümkün değildir. Kiraya veren aleyhine hükme bağlanan müsadere kararı ise bu sözleşmenin varlığına rağmen hüküm ve sonuç doğurabilir. Çünkü kiracı iyiniyetli olsa dahi, bu sözleşmeyle onun lehine bir ayni hak tesis edilmediği için TCK m. 54/1'e göre müsadereye karar verilebilir. Kira sözleşmesi devam ederken ise gerek kiraya verenin gerekse kiracının borçları sebebiyle ve hatta finansal kiralama bedeli sebebiyle hacze karar verilmesi mümkün değildir ${ }^{26}$. Şöyle bir durum var ki, müsadere kararı kesinleştiği tarihe kadarki dönemde tahakkuk etmiş ve tahsil edilmemiş kira bedeli, kiraya verenin alacaklıları lehine IIIK m. 89 hükmüne göre muhafaza altına alınabilmelidir. Müsadere

03/02/2019). O hâlde, özel sicile kaydedilmemiş ve noter huzurunda gerçekleşen araç satımında mülkiyet, alıcıya geçmiş olur. Şartları oluştuğu takdirde verilen müsadere kararına karşı, böyle bir durumda satıcı, TCK m. 54/1 hükmüne istinaden iyiniyet iddiasında bulunamayacaktır.

23 Hukuki niteliği tartışmalı olmakla birlikte, TMK m. 764'e göre yapılan böyle bir sözleşmenin taliki şarta bağlanmış bir sözleşme olarak kabulü gerekir, bkz. ASLAN, 2005a, s. 131.

24 ALTUĞ, 2017, s. 185.

25 ASLAN, 2005a, s. 129-146.

26 KURU, 2013, s. 597-600. 
kararının bu bedel bakımından hüküm ve sonuç doğurması ise mümkün değildir. Kararın kesinleşmesinden sonra tahakkuk eden kira bedelleri ise devlete ait olacağı için kiraya verenin borçları sebebiyle bu bedel hakkında İİK m. 89'a göre muhafaza tedbiri uygulanamaz.

\section{3- Müsadereye Karar Verilmesi ve Müsadere Kararının Hüküm ve Sonuçlarını Doğurduğu An}

Genellikle asıl ceza davasında müsadere hususu da karara bağlanmaktadır ${ }^{27}$. Ceza davasının açılmadığı veya açılmış davada müsadere hakkında bir karar verilmediği hâllerde ise ayrı bir müsadere davası açılması ihtiyacı doğar. Böyle bir durumda, CMK (Ceza Muhakemesi Kanunu) m. 266/1 hükmü gereğince, Cumhuriyet savcısı veya kat1lan müsadere kararı verilmesi için başvuruda bulunabilir ve duruşma yapılması suretiyle müsadere talebi hükme bağlanır. Her iki hâlde de müsadereye karar verildikten sonra CMK m. 258'e göre kanun yoluna başvurulabilir. Kanun yoluna başvurabilecek kişiler ise Cumhuriyet savcısı, katılan ve müsadere konusu şey üzerinde hak sahibi üçüncü kişidir.

Müsadere konusu şey hakkında icra takibi başlatmış veya bunun haczini talep etmiş takip alacaklısının katılan sıfatıyla müsadere muhakemesine iştirak edip edemeyeceği üzerinde de durulmalıdır. CMK m. 237/1 hükmünde malen sorumlu olan kişilerin de kamu davasına katılabileceği öngörülmüştür. Malen sorumlu kişi ise CMK m. 2/1 (i) düzenlemesine göre verilecek hükmün sonuçlarından etkilenecek veya bunlara katlanacak kişidir. Yerine göre icra takibinin tarafları veya üçüncü bir kişi (alıcı gibi) malen sorumlu kişi olarak görülebilmelidir. Mesela, takibe konu şey (ayni hakka ilişkin ilama dayalı takibe göre alacaklıya iadesi gerekiyorsa veya rehnin paraya çevrilmesi yoluyla takipte rehinli malvarlı̆̆ de ğeriyse) üzerinde müsadere kararı verilme ihtimali varsa takip alacaklısı, malen sorumlu sıfatıyla müsadere muhakemesine katılabilmelidir.

Kanun yoluna başvurulmasında müsadere konusu şeyin değerinin bir önemi haiz olup olmadığı ele alınması gereken bir konudur ${ }^{28}$. Çünkü kanun yoluna başvurulmasın-

27 ZAFER, 2016, s. 644; ARTUK/GÖKÇEN/YENIDÜNYA/ÇAKIR, 2018, s. 908.

28 Bu hususta bkz. GEDİK, 2016, s. 285-289. 
da parasal sınıra göre kanun yolu başvurusunun caiz olup olmadığı yönünde bir değerlendirme yapılıp yapılamayacağı tartışması doğabilir. Şöyle ki, sadece belirli bir parasal sınırın üzerindeki müsadere kararlarına karşı kanun yoluna gidilebileceği düşünülebilir. Asıl ceza davası ile birlikte müsadereye karar verilmiş ise Yargıtay CGK, müsadere kararını hükmün bir parçası olarak görmektedir. Buna göre, asıl davada verilen hükme göre kanun yoluna gidilip gidilmeyeceği belirleyicidir ${ }^{29}$. Buna karşın, kamu davası hiç açılmamışsa veya açılmış olmasına rağmen hükümle birlikte müsadere hakkında bir karar verilmemişse, müsadere için ayrı bir muhakeme yapılması (bkz. CMK m. 256) gerekebilir. Bu şekilde müsadere kararı verildiğinde, kanun yoluna başvurulurken müsadere konusunun değerine bakılmasının gerekip gerekmeyeceği belirlenmelidir. Yarg1tay CGK, 04/06/1936 sayılı İBK ${ }^{30}$ çerçevesinde, bu hususta müsadere konusu malvarl1ğ1 değerinin dikkate alınması gerektiğine ve kanun yoluna başvurulması bakımından HUMK (şimdi HMK) hükümlerinin uygulanabileceğine karar vermiştir ${ }^{31}$. Buna göre, bu kapsamdaki bir müsadere kararı, HMK m. 341 ve 362'de geçen parasal sınırlara bağ11 olarak yerine göre istinaf ve temyiz edilebilir. Müsadere kararı hakkında kanun yoluna başvurulmasında sözü geçen hükümlere göre bir değerlendirme yapılması, haklı ola-

29 Yargitay CGK, E. 2014/6-66, K. 2014/365, T. 11.07.2014 (Kazancı Bilişim - İçtihat Bilgi Bankası, Erişim Tarihi: 03/04/2019); Yargitay CGK, E. 2014/6-66, K. 2014/365, T. 11.07.2014 (Kazancı Bilişim - İçtihat Bilgi Bankası, Erişim Tarihi: 03/04/2019). Bu kararlarda öncelikle sanık hakkında hükmün açıklanmasının geri bırakılması karar verildiği ve bu karara karşı ise itiraz kanun yoluna başvurulabileceği belirtilmiştir. Daha sonra hükmün parçası olan müsadere kararının da itiraz kanun yoluna tabi olduğu belirtilmiştir. Asıl ceza davasında hükmün açıklanmasının geri bırakılmasına karar verilen bu gibi hâllerde müsadereye karar verilip verilmeyeceği hususunda farklı görüşler ileri sürülmektedir. Bir görüşe göre, hükmün açıklanmasının geri bırakılmasına karar verilse bile, müsadere kararı verilebilir, bkz. ARTUK/GÖKÇEN/YENIDÜNYA/ÇAKIR, 2018, s. 903. Buna karşın, TCK m. 54/1, 2. cümledeki ve m. 54/4'deki hükümlere göre müsaderenin uygulanması ayrık kalmak kaydıyla, hükmün açıklanmasının geri bırakılmasına karar verilen bir durumda müsadereye de karar verilmesi, Anayasa’ya aykırı görülmektedir, bkz. GÜNGÖR/TOROSLU, 2016, s. 1977, 1978.

30 Yargıtay İBGK, E. 1935/80, K. 1936/14, T. 04.06.1936 (Kazancı Bilişim - İçtihat Bilgi Bankası, Erişim Tarihi: 03/04/2019): "Ceza yasası acısından ceza ile birlikte söz konusu olduğu yerlerde ceza hükümlülügünün yasal sonuçlarından olan zoralım hususu, esas davadan ayrı ve bağımsız bir dava halinde esası incelemeye görevli olan mahkemelerde kayıtsız şartsı inceleme konusu olabilir. Aynı şekilde Yargıtay'da da incelenebilir. Temyiz edilebilme sınırında HUMK [şimdi HMK] esas alınır.”.

31 Yargitay CGK, E. 2011/3-189, K. 2011/267, T. 13.12.2011 (Kazancı Bilişim - İçtihat Bilgi Bankası, Erişim Tarihi: 03/04/2019); Yargitay CGK, E. 2013/9-421, K. 2016/440, T. 22.11.2016 (Kazancı Bilişim - İçtihat Bilgi Bankası, Erişim Tarihi: 03/04/2019). Yargıtay 19. CD de CMK (Ceza Muhakemesi Kanunu) m. 256 hükmü kapsamındaki müsadere kararları hakkında hukuk yargısındaki parasal sınırların dikkate alınacağı yönünde karar vermiştir, bkz. Yargıtay 19. CD, E. 2016/1089, K. 2017/11103, T. 14.12.2017 (Kazancı Bilişim - İçtihat Bilgi Bankası, Erişim Tarihi: 03/04/2019). 
rak uygun bulunmamaktadir ${ }^{32}$. Kanun yoluna başvurmak, AY (Anayasa) m. 36'da geçen hak arama hürriyetinin bir gereğidir ${ }^{33}$; bu hakkın özüne dokunmaksızın ${ }^{34} \operatorname{kanun}^{35}$ ile bir sınırlandırma getirilebilir. CMK m. 256'ya göre verilen müsadere kararları bakımından, parasal değere göre kanun yoluna başvurulmasını sınırlayıcı mahiyetteki HMK m. 341 ve 362'ye atıf yapan açık bir kanuni düzenleme ise yoktur. Bu sebeple, müsadere konusunun değerine bakılmaksızın, müsadere kararları hakkında her hâlükârda kanun yoluna gidilebilmelidir. Kanun yoluna gidilebileceğinden ancak kanun yolu incelemenin tamamlanmasına (hükmün kesinleşmesine) bakılarak mülkiyetin devlete geçip geçmediği belirlenebilir.

Müsadereye karar verilen diğer bir durum ise suç konusu olmayan ve fakat koruma müsaderesine tabi eşya açısındandır. Müsadereye bu hâlde karar verme görevi, sulh ceza hâkimliğine ait olup; duruşma yapılmasına da gerek yoktur. Sulh ceza hâkimliğince verilen bu nitelikteki kararlar aleyhine itiraz yoluna başvurulabilir. İtiraz yoluna başvurabilecek kişiler ise CMK m. 258'de zikredilen kişilerdir ${ }^{36}$. İtiraz üzerine merci tarafından verilen kararlar kesindir (CMK m. 271/4). Yani müsadere kararı gereğince mülkiyetin devlete geçmesi, itiraz üzerine verilen bu karar ile gerçekleşmektedir.

İcra takibinin takip borçlusuna ait malvarlığına yönelik kanuni bir yol olduğu düşünüldügünde, müsadere kararının hüküm ve sonuçlarını doğurduğu an, derdest takip açısından büyük bir öneme sahiptir. Her ne kadar müsadere kararı mülkiyetin devlete geçmesi sonucunu da doğursa, mülkiyetin devlete geçmesi, bu kararın kesinleştiği tarih-

32 GEDİK, 2016, s. 287, 288.

33 ALANGOYA, Yavuz, "Kanun Yolunun Anayasal Temeli ve HUMK m. 427 Hükmü ile Kanun Yolu Kapatılmış Olan Kararlara Karşı Kanun Yoluna Müracaat İmkanı”, Makaleler, Beta Yayınevi, İstanbul, 2012, s. 231-233.

34 Bu noktada, özellikle vurgulanan husus ise yargının işlevini yerine getirmesi adına sınırlandırma getirilebileceği yönündedir, bkz. ALANGOYA, 2015, s. 238-240.

35 Parasal değere göre kanun yoluna başvurulmasının kanun ile sınırlandırılması, AYM (Anayasa Mahkemesi) tarafindan da uygun görülmektedir, bkz. AYM, E. 2006/65, K. 2009/114, T. 23.07.2009 (RG 7 Ekim 2009, S. 27369). Fakat getirilecek bu sınırlamanın adli para cezalarında olduğu gibi açıç̧a hükme bağlanması şarttır.

36 Bu hâlde, kanun yoluna başvurmaya ilişkin olan CMK m. 260 hükmünün uygulanabileceği belirtilmiştir, bkz. ARTUK/GÖKÇEN/YENIDÜNYA/ÇAKIR, 2018, s. 646, 647. Oysa CMK m. 258'deki açık hüküm dikkate alındığında, CMK m. 260'a göre kanun yoluna başvurulabileceğini söylemek güçtür. 
te gerçekleşir ${ }^{37}$. Öyleyse hakkında müsadere kararı verilmiş bir malvarlığı değeri aç1sından da icra takip işlemleri yapılabilmelidir. Müsadere kararı kesinleştikten sonra ise artık o malvarlığına yönelik olarak cebri icra işlemlerinin yapılması kural olarak mümkün değildir. Bu ayrıma göre, haczin uygulandığı tarih büyük bir önemi haizdir. Söz gelimi, haczin tapuya bildirilmesi muhafaza tedbiri olup; TMK (Türk Medeni Kanunu) m. 1010'a göre yapılan şerhten önce de haciz gerçekleşmiş olur ${ }^{38}$. Müsadere kararı haczin tapuya bildiriminden önce kesinleşmemişse, hacizden sonraki takip işlemleri müsadere kararı kesinleşinceye icra edilebilmelidir.

\section{B- İcra Takibine Konu Malvarlığı Değeri Hakkında Müsadere Kararı Verilmesi}

İcra takibinin konusu bir para alacağı olabileceği gibi bunun dışındaki bir malvarlığı değeri de olabilir. Konusu paradan başka bir şey olan taşınır ve taşınmaz malların teslimine yönelik ilamlı takipte bunlar hakkında verilen müsadere kararı takibe konu şey

37 SOYGÜT-ARSLAN, 2014, s. 209. ACK m. 75'te bu yönde bir düzenlemeye açıcça yer verilmiştir. Kararın kesinleşmesi ile mülkiyet geçtiği için bu amaçla zilyetliğe elkonulması şart olmadığı gibi, devre yönelik ayrıca bir işlem yapılmasına da ihtiyaç yoktur, bkz. Heuchemer: Beck'scher OnlineKommentar zum Strafgesetzbuch (Hrsg.: von Heintschel-Heinegg, Bernd), 34. Ed., München, 2017 (BeckOK StGB), § 75 kn. 2, 3.

38 ÜSTÜNDAĞ, Saim, İcra Hukukunun Esasları, 8. Bas1, Yaylacık Matbaacılık, İstanbul, 2004, s. 158; MUŞUL, Timuçin, İcra ve İflâs Hukuku, C. I, 6. Bası, Adalet Yayınevi, Ankara, 2013, s. 520. Hacze iştirak konusunda ilk haczi belirlemeye yönelik görüşler ise aksi yöndedir. Yargı kararları 1ş1ğında TMK m. 1010 hükmüne uygun olarak tapuda haciz şerhinin konulduğu (kararın icra edildiği) tarihte haczin gerçekleştiği savunulmaktadır, bkz. YILMAZ, Ejder, "Hacze Takipsiz Katılma (Hacze Adi İştirak)", Ankara Üniversitesi Hukuk Fakültesi Dergisi, Y1l: 1973, Cilt: 30, Sayı: 1, s. 281; ÖZEKES, Muhammet, İcra ve İflâs Hukukunda İhtiyati Haciz, Seçkin Yayınevi, Ankara, 1999, s. 300; AKCAN, Recep, Hacze İştirak, Seçkin Yayınevi, Ankara, 2005, s. 56, 57. Tapuya bildirimin esas alınması gerektiği yönündeki başka bir görüşe göre ise borçluya veya onun adına tebliğ yapılabilecek kişiye tebliğ evrakı teslim edilmişse haciz bu tarihte; aksi hâlde ise tapuya bildirim tarihinde gerçekleşmiş olur, bkz. POSTACIOĞLU, İlhan E./ALTAY, Sümer, İcra Hukuku Esasları, 5. Bası, Vedat Yayınevi, İstanbul, 2010, s. 363. Söz konusu bu görüşler bağlamında, müsadere kararının kesinleştiği an, haciz şerhi konulmadan önce ise devletin mülkiyet hakkına dayanarak istihkak iddiasında bulunması mümkün olur. Daha isabetli gördüğümüz bir görüşe göre ise ilk haczin tespitinde icra dairesinin iradesini ortaya koyduğu an esas alınmalıdır, bkz. MERİÇ, Nedim, Türk-İsviçre İcra Hukukunda Paylaştırma Kuralları ve Sıra Cetveline Müracaat Yolları, Yetkin Yayınevi, Ankara, 2015, s. 131, 132. Hacze yönelik iradenin oluşması, haczedilecek malvarlığının bilinmesi ile mümkün olmaktadır. Fiili hacizlerde bu, malvarlığının haciz yerinde tespiti mümkün olduğundan dolayı, haciz yerinde mümkün olabilir. Sicile kayıtlı bir malvarlığı hakkında ise bu iradenin ortaya çıkması, hangi malvarlığının haczedileceği bilinebileceği için o anda mümkün olabilir. Yani bu gibi durumlarda haczin gerçekleşmesi, müzekkerenin ulaşmasına bağlanmamalıdır. O hâlde, yalnızca bu iradenin ortaya konulduğu andan önce müsadere kararı kesinleşmişse, devlet lehine istihkak iddiasında bulunulabileceği kabul edilmelidir. 
hakkında verilmiş olur. Öte yandan, rehnin paraya çevrilmesi yoluyla takipte, alacağı güvence altına almak için rehin gösterilmiş malvarlığı hakkında da müsadere kararı verilmesi lüzumu doğabilir. Her iki hâlde de müsadere kararı verilmesi sebebiyle takip işlemlerine devam edilmesinde tereddütler yaşanabilir.

Konusu para alacağı dışında olan ilamlı takipte, takip konusu şeyin müsaderesinin mümkün olup olmadığı, ilamın muhtevasına bağlı olur. Böyle bir durumda, ilama göre takip alacaklısına aidiyetine karar verilen malvarlığı değeri hakkında TCK m. 54/1 hükmü gereğince zaten müsadereye karar verilmemelidir. Diğer bir ifadeyle, takip alacaklısı lehine ayni bir hakkın varlığı yönünde hüküm kurulmuşsa, müsaderenin bu hak bakımından mümkün olmadığı kabul edilmelidir. Pek tabi ki, takibe konu kararın verildiği an (inşai hükümler bakımından) da önemli arz edebilir ${ }^{39}$. İlamın ayni bir hakka dayanmadığı hâllerde ise müsadere kararı verilmesi mümkündür. Şahsi bir hakka dayanan ve taşınır veya taşınmaz bir malın teslimine yönelik ilamlı icra takibi, o malın müsadere edilmesi durumunda devam edemeyecektir ${ }^{40}$. Aynı şekilde, TCK m. 54/1, 2. cümlenin veya TCK m. 54/4'ün kapsamına giren bir malvarlığı değeri de müsadere edilebilmelidir. Bu sefer ilamın içeriğine bakmaya gerek kalmaz. Nitekim eşyanın varlığı, başlı başına bir müsadere sebebi teşkil etmektedir.

39 Hukuk davası açılmadan önceki bir tarihte müsadere kararı gereğince mülkiyet devlete geçmişse, öncelikle hak sahipliğine yönelik bir hukuk davası açılmalıdır. Bu dava kazanıldıktan sonra ise CMK m. 311/1 - (d) hükmü gereğince yargılamanın iadesi başvurusunda bulunulmalıdır. Hukuk davasının görüldüğü anda da müsadere kararı hüküm ve sonuçlarını doğurmuş olabilir. Bu takdirde, davanın konusuz kaldığı yönünde bir karar dahi verilebilir. Bu durumda, zaten o malvarlığı değeri hakkında icra takibinin yapılması ihtimalinden de söz edilemez. Aslında hukuk davasının görüldüğü anda müsadere kararı verilmemesi daha isabetlidir. Bu durumda, gerçekte aleyhine müsadere kararı verilen kişiye ait olmayan bir malvarlığı değerinin müsaderesine karar verilmiş olur. Dolayısıyla, müsadere muhakemesinde CMK m. 218 gereğince hukuk davasının bekletici sorun yapılmasının isabetli olacağı kanaatindeyiz. Nitekim Yargıtay CGK (Ceza Genel Kurulu), müsadere konusu hakkında üçüncü kişilerin hak iddiası bulunması hâlinde bu hususun hukuk mahkemelerinde karara bağlanabileceğine işaret etmiştir, bkz. Yargıtay CGK, E. 2014/11-312, K. 2017/11, T. 17.01.2017 (Kazancı Bilişim - İçtihat Bilgi Bankası, Erişim Tarihi: 03/04/2019). Bu da göstermektedir ki müsadere davasına bakan mahkeme, CMK m. 218'e göre hukuk davasını bekletici sorun yapabilmelidir.

40 Takip alacaklısının malik olduğu ve şahsi bir hakka dayanarak icra takibi başlattığı hâllerde (kira sözleşmesine göre tahliye) ise müsadereye zaten karar verilemez. Nitekim TCK m. 54/1 anlamında iyiniyetli üçüncü bir kişiye (takip alacaklısına) ait olan bir malvarlığ 1 değeri söz konusu olur. Çalışmamızda, şahsi hakka dayalı başlatılan icra takibi ile mülkiyeti takip borçlusuna ait olup; bir sebepten ötürü takip alacaklısına teslimi gereken malları kastetmekteyiz. 
Yargıtay'a göre, rehnin paraya çevrilmesi yoluyla takip yapılmakta iken müsadereye karar verilirse artık o takibe devam edileme ${ }^{41}$. Bundan sonra artık borçlu aleyhine haciz yoluyla takip yapılmalıdır. Karara gerekçe olarak ise bu hususta müsadere kararı ile rehin hakkının sona ermiş olduğu gösterilmiştir. Bu kararın TCK m. 54/1 hükmü ile bağdaştırılması mümkün değildir. 6763 sayılı K. m. 11 ile eklenen "Eşyanın üzerinde iyiniyetli üçüncü kişiler lehine tesis edilmiş sınırlı ayni hakkın bulunması hâlinde müsadere kararı, bu hak saklı kalmak şartıyla verilir." hükmü uyarınca, müsadere kararı verilmesine rağmen rehin hakkı sona ermemelidir. Kaldı ki, müsadere kararı bu hakkın sona ermesine yönelik olarak verilemez.

Bununla birlikte, rehin hakkı sahibinin suçtan haberdar olup olmadığına da bakılmalıdır. Suça katılma iradesinin olup olmaması, TCK m. 54/1, 1. cümlede "iyiniyet" kavramı ile ifade edilmiştir ${ }^{42}$. Şayet müsadere konusu şey üçüncü bir kişiye aitse ve o kişi suç işlendiğinden haberdar değilse, müsadere kararı verilemez ${ }^{43}$. Bunun gibi, üçüncü kişilere ait sınırlı ayni haklar TCK m. 54/1, 3. cümle gereğince müsadere edilemez. O hâlde, suçtan haberdar olan rehin hakkı sahibi, müsadere kararına katlanmak durumunda kalmalıdır. Eğer bu yönde bir irade yoksa rehin hakkı sona ermemeli ve rehnin paraya çevrilmesi yoluyla takibe devam edilebilmelidir.

Buna karşın, TCK m. 54/1, 2. cümlede geçen şartların varlığı hâlinde, üçüncü kişiye ait olmakla birlikte suçun işlenmesinde kullanılmak üzere hazırlanan bir eşya müsadere edilebilmelidir. İcra takibine konu olması zor bir ihtimal olmakla birlikte, TCK m. 54/4'e göre müsaderesi mümkün olan bir malvarlığı hakkında da aynı şeyi söylemek mümkündür. Bu hüküm kapsamına giren bir eşya üzerinde bu niteliği bilinmediği için rehin hakkının geçerli olarak tesis edildiği düşüncesiyle icra takibi başlatılmış olabilir. Rehin hakkı böyle bir durumda geçersiz olduğu için kamu düzenine aykırılık sebebiyle takibin iptali her zaman için şikâyete konu edilebilir. Diğer bir ifadeyle, rehin hakkı geçersiz oluğu için rehnin paraya çevrilmesi yoluyla takip hiçbir şekilde başlatılamaz.

41 Yargitay 12. HD, E. 2017/2353, K. 2017/7156, T. 04.05.2017 (Kazancı Bilişim - İçtihat Bilgi Bankas1, Erişim Tarihi: 03/04/2019).

42 CENTEL/ZAFER/ÇAKMUT, 2017, s. 742.

43 CENTEL/ZAFER/ÇAKMUT, 2017, s. 737. 
Buna rağmen hatalı bir şekilde rehnin paraya çevrilmesi yoluyla takip yapılmış ve paraya çevirme işlemi tamamlanmış olsa dahi müsadere kararı yine uygulanabilecektir. Bu sebeple, müsadere konusu hakkında yürütülmekte olan takibe bakılmaksızın, TCK m. 54/1, 2. cümle ve 54/4'e tabi malvarlığı değeri hakkında her hâlükârda müsadereye karar verilebilmelidir.

\section{C- Haczedilmiş Malvarlığı Değeri Hakkında Müsadere Kararı Verilmesi}

Haciz işlemi ile borçluya ait olan bir malvarlığı bakımından borçlunun sadece tasarruf yetkisi kısıtlanmaktadır. Bu işleme rağmen borçluya ait olan mülkiyet hakkı sona ermediğinden ötürü, hacizli mal ve hakların müsaderesi yönünde karar verilmesi kuvvetle muhtemeldir. Müsadere karar verildiği takdirde haciz işleminin geçerliliği tartışma konusu hâline gelir.

\section{1- Haciz İşleminin Geçerliliği}

Haciz işlemi ile takip alacaklısına hacizli malvarlığı bakımından bir ayni hak tanınmış olmaz ${ }^{44}$. Bununla birlikte, takip borçlusunun hacizli malvarlığı üzerindeki mülkiyet hakkı da sona ermez ${ }^{45}$. Dolayısıyla, bir kişinin haczedilmiş bir malvarlığı değerinin de müsaderesine karar verilebilir. Haciz işlemi uygulandıktan sonra, yalnızca borçlunun hacizli mal ve hak üzerindeki tasarruf yetkisi kısıtlanır. Haciz gerçekleşse de borçlu tarafından tasarrufta bulunulması mümkün olmakla birlikte, takip alacaklısına zarar verdiği ölçüde bu tasarruf işlemi, İIKK m. 86/3 hükmünce geçersiz görülmelidir ${ }^{46}$. Bununla birlikte, İIKK m. 86/2'de diğer tarafın iyiniyetli olması kaydıyla yapılan işlem geçerli olur ${ }^{47}$. Müsaderede ise devre yönelik bir hukuki işlem yoktur ve herkes bak1mından sonuç doğurma söz konusudur ${ }^{48}$. Hâl böyle olunca, mülkiyetin müsadereye da-

44 YILDIRIM, Mehmet Kâmil/DEREN-YILDIRIM, Nevhis, İcra ve İflas Hukuku, 7. Bası, Beta Yay1nevi, İstanbul, 2016, s. 134.

45 ÜSTÜNDAĞ, 2004, s. 162; MUŞUL, 2013, s. 519.

46 KURU, 1997, s. 457; ÜSTÜNDAĞ, 2004, s. 162-164; ASLAN, 2015a, s. 115; POSTACIOĞLU/ALTAY, 2010, s. 362; KURU, 2013 s. 432.

47 İyiniyetin ileri sürülemeyeceği hâllerde (Ör. haczin TMK m. 1010'a göre tapuya şerh edilmesi) ise mülkiyetin kazanılması mümkün değildir, bkz. ÜSTÜNDAĞ, 2004, s. 162-165.

48 Heuchemer: Beck'scher Online-Kommentar zum Strafgesetzbuch (Hrsg.: von Heintschel-Heinegg, Bernd), 34. Ed., München, 2017 (BeckOK StGB), § 75, kn. 3. 
yalı olarak geçmesi, İIKK m. 86/2 kapsamında görülmemelidir. Diğer bir ifadeyle, devletin iyiniyet kaidelerine istinaden iktisapta bulunmadığı açıktır.

Bununla birlikte, TCK m. 54/1, 3. cümleye göre, müsadere kararı verilirken sadece üçüncü kişilere ait ayni hakların saklı tutulabileceği ve müsadere edilen malvarlığ üzerindeki üçüncü kişilere ait başka her türlü hak ve yetkinin (haciz de dâhil olmak üzere) dikkate alınmayacağı sonucuna varılabilir. O hâlde, bir malvarlığı değeri hakkında haciz işlemi uygulanmış olsa dahi müsadereye karar verilmesi mümkündür. Haczin bu şekilde sonra ermesi bakımından, TCK m. 54/1, 3. cümle dikkate alındığında, haczin sona ermesi bakımından kanunilik ilkesine ${ }^{49}$ uygun bir sonuç ortaya çıkmaktadır. Fakat şunu belirmeliyiz ki, haciz işleminin bu şekilde sona ermesi, takip alacaklısının alacağını güvence altına alan ve bu yönüyle onun bir unsuru hâline gelen haczin dikkate alınmaması, pek de isabetli değildir. Haciz işleminin varlığı hâlinde müsaderenin hacizli malvarlığı değeri bakımından gerçekleşmemesi, aslında müsaderenin devlet için bir gelir elde etme aracı olmadığı yönündeki anlayışla da uyumlu olacaktır. Bu sebeple, TCK m. 54/1, 3. cümlesindeki düzenlemenin olması gereken hukuk bakımından sadece sınırlı ayni haklara hasredilmemesi gerektiği kanaatindeyiz.

Güvenlik tedbiri olan müsaderenin amacı da dikkate alındığında, hacizli malvarlığı değeri hakkında müsadere kararı verilmemesinin daha isabetli olduğunu söyleyebiliriz. Ceza hukukunda güvenlik tedbirleri ile tehlikelilik durumu göz önünde tutulmakta ve toplumun savunulması amaç edinilmektedir ${ }^{50}$. Gerçekleşmiş eylemin arz ettiği tehlike dikkate alınmakta ve buna bağlı olarak bir yaptırım olarak müsadere konusu ilgiliye iade edilmemektedir. Hacizli malın da paraya çevrilmesi ve bunun sonucu olarak borçluya iade edilmemesi söz konusudur. Bazı hâllerde ise ilamlı icra neticesinde takip konusu şeyin aynı şekilde takip alacaklısına teslimi gerçekleşir. Dolayısıyla, müsadereye karar verilmese dahi, icra takibi neticesinde borçluya ait malvarlığ borçlunun elinden çıkmaktadır.

49 ÖZEKES, 1999, s. 89-91; KÖKSOY, Mesut, İcra Hukukunda Hukuki Güvenlik İlkesi, Adalet Yayınevi, Ankara, 2018, s. 47, 48.

50 GEDIKK, 2016, s. 101. 
Her ne kadar TCK m. 54/1, 3. cümle hükmüne göre hacizli mal ve hakların da müsaderesine karar verilmesi mümkün de olsa, bu karar kesinleşmeden mülkiyet devlete geçmeyeceği için kararın kesinleşmesi anına kadar geçen sürede haczin muteber kalacağı kabul edilmelidir. Öyle ki, mülkiyetin devlete geçtiğinin kabul edildiği ana kadar olan süreçte satış işleminin yapılması dahi mümkün görülmelidir. Zira müsadereye karar verilmiş olsa dahi takip borçlusunun mülkiyet hakkı sona ermemektedir. Öte yandan, müsadere kararı verildikten ve fakat kesinleşmeden önceki bir aşamada da borçlunun mülkiyet hakkı devam ettiği için haciz işlemi gerçekleşebilmelidir. Bu bağlamda, müsadere kararı kesinleşmeden önce paraya çevirme işleminin tamamlanması sağladığı takdirde alacaklının o hacizli malvarlığı değerinin bedeli ile tatmin edilebileceğini söyleyebiliriz.

Eşya müsaderesinin bir türü olarak kısmi müsaderenin de mümkün olduğu, TCK m. 54/5 hükmünde öngörülmüştür. İIK m. $128 / 5$ 'te ticari ve ekonomik bütünlük arz eden ya da bütün hâlinde satıldığında daha yüksek gelir elde edileceği anlaşılan mal ve hakların birlikte paraya çevrileceği öngörülmüsstür. Doğal olarak, haciz işleminin de bu mal ve hakların tamamı bakımından uygulanması daha isabetli olur. Bu yüzden, kısmi müsadereye konu edilecek mal ve hak da bu duruma rağmen haczedilebilmelidir. Bir malvarlığı değerinin müsadereye konu edilme ihtimalinin varlığı hacze engel değildir. Kısmi müsadere uygulanacak olması da bunu değiştirmemelidir. Buna karşın, müsadere kararı kesinleşmiş ve mülkiyet devlete geçmiş ise kısmi müsadereye konu malvarlığı haczedilemez ve eğer bir haciz varsa TCK m. 54/1, 3. cümle uyarınca bunun sona ermesi söz konusu olur. Paraya çevirme usulü İIK m. 48'de belirtildiği üzere, bu hâlde İİK m. 106 vd. hükümlerine göre gerçekleşemez. Aslında bu gibi bir durumda birlikte paraya çevirmenin kabulü, olması gereken hukuk bakımından tercih edilmelidir. Paraya çevirme sonucu daha fazla bir bedel elde edilebileceğinden hem takip alacaklısının hem de devletin menfaatine bir durum elde edilebilir.

\section{2- Haciz İhbarnamesi Gönderilmesi}

Müsadere kararının kesinleştiği tarihe göre haciz anının belirlenmesi açısından İIK m. 89 açısından ayrıca bir değerlendirme yapılmalıdır. Takip borçlusunun üçüncü bir kişiden olan alacağının haczedilmesinde, İIK m. 89 hükmüne göre haciz ihbarnamesi 
gönderilir. Özellikle kazanç müsaderesine karar verilmesi hâlinde, üçüncü kişideki alacağın İIKK m. 89 kapsamında tahsil edilip edilemeyeceği sorusu ile karşılaş1lır ${ }^{51}$. İhbarnamenin gönderilmesi ile amaçlanan husus ise üçüncü kişinin uhdesindeki mal ve hakkın muhafaza altına alınmasıdır. Bu özelliği itibariyle haciz ihbarnamesi, bir muhafaza tedbiri olarak görülür ${ }^{52}$. Müsadere kararına rağmen takip alacaklısına ödeme yapılıp yapılmayacağı, İIK m. 89 hükmüne göre yapılan işlemlerde haciz anının belirlenmesine bağlıdır. Üçüncü kişi açısından haczin etkilerinin doğmasına yönelik bu ihbarnamenin öncesinde bir haciz kararı alınmaktadır ${ }^{53}$. Dolayısıyla, müsadere kararı açısından haciz kararının verildiği an dikkate alınmalıdır. Nitekim ihbarnamenin gönderilmesi kurucu değildir; sadece açıklayıcı bir etkiye sahiptir ${ }^{54}$.

$\mathrm{Bu}$ bağlamda, müsadere kararının kesinleşmesi noktasında, haciz ihbarnamesinin ulaştığg tarih değil, icra dairesince üçüncü kişide olduğu düşünülen mal ve hakların haczine karar verildiği tarih önemlidir. Bundan sonraki bir tarihte ise müsadere kararı kesinleşse de takip alacaklısına ödeme yapılabilmelidir. Takip alacağı karşılandıktan sonra ise geriye kalan bir kısım olursa bu kısım takip borçlusuna iade edilmemelidir. Çünkü geri kalan kısım açısından mülkiyet hakkı artık takip borçlusuna ait değildir.

51 Yargıtay'ın vermiş olduğu bir kararda aleyhine müsadere kararı verilme ihtimali olan kişinin bir banka şubesindeki hesabında bulunan para bakımından müsaderenin mümkün olup olmadığı değerlendirmesi yapılmıştır, bkz. Yargıtay 10. CD, E. 2007/2157, K. 2007/3988, T. 11.06.2007 (Kazancı Bilişim - İçtihat Bilgi Bankası, Erişim Tarihi: 15/06/2019). Bu karardan hareketle, İIK (İcra ve İflâs Kanunu) m. 89'un uygulanmasını gerektiren hâllerde müsadere kararı bakımından bir değerlendirme yapma ihtiyacının doğabileceği söylenebilir.

52 ASLAN, Kudret, "Hacizde Sıra (Tertip)", Ankara Üniversitesi Hukuk Fakültesi Dergisi, Yıl: 2005, Cilt: 54, Sayı: 2, s. 547; AKİL, Cenk, Borçlunun Üçüncü Kişilerdeki Mal ve Alacaklarının Haczi, Yetkin Yayınevi, Ankara, 2013, s. 166, 439; YILDIRIM/DEREN-YILDIRIM, 2016, s. 167.

53 YAVAŞ, Murat, Borçlunun Üçüncü Şahıslardaki Mal, Hak ve Alacaklarının Haczi (İIK m. 89), Arıkan Yayınevi, İstanbul, 2005, s. 19.

54 Haczin tekemmülüne ilişkin görüşler çerçevesinde İIK m. 89'a göre gönderilen ihbarnamenin haczin geçerliliği için bir şart olmadığı ileri sürülmüştür, bkz. ÜSTÜNDAĞ, 2004, s. 147. Bu bağlamda, haciz ihbarnamesinin gönderilmediği bir aşamada da üçüncü kişideki malvarlığı değerinin haczedildiği söylenebilir. İIK m. 88 ve 89'un üst başlığ olan “Mahcuz mallart muhafaza tedbirleri” şeklindeki başlıktan hareket edilerek haciz ihbarnamesinin muhafaza tedbiri niteliğinde olduğu belirtilmektedir. Dolayısıyla, icra dairesince haciz kararı verildiği anda haciz gerçekleşmiş olarak görülmelidir, bkz. MUŞUL, 2013, s. 600; KURU, 2013, s. 463. Buna karşın, haciz ihbarnamesinin bildirilmesi ile haczin tekemmül edeceği görüşü de savunulmaktadır, bkz. KARAKAŞ, Cemal Fazıl, "Haciz Sıra Cetvelinin Şekli”, Prof. Dr. Saim Üstündă̆'a Armağan, Seçkin Yayınevi, Ankara, 2009, s. 302; AKCAN, 2005, s. 125. 


\section{II- Müsadereye Karar Verilmesi ve İcra Takip İşlemlerinin Yapılması}

Müsadere muhakemesine başlanmadan önce bir koruma tedbiri olarak elkoyma kararı verilebilir. Niteliği itibariyle müsadereden farklı olan elkoyma, bir koruma tedbiri olup; ilgili kişinin belirli bir malvarlığı değeri üzerindeki tasarruf yetkisini kısıtlamaya yöneliktir. Ya muhakemede delil olarak kullanılacağından (önleme elkoyması) ya da müsadereye konu edileceğinden (adli elkoyma) bir malvarlığg değeri hakkında CMK m. 123/1 gereğince elkoyma kararı verilir ${ }^{55}$. Bu sebeple, elkoyma çoğunlukla müsadere ile sıkı bir ilişki içinde olur. Haczi kabil olması kaydıyla elkoyma kararına konu olacak malvarlığı değeri de icra takip işlemlerini yakından ilgilendirebilir.

\section{A- Müsadereye Karar Verme Sürecinde İcra Takip İşlemlerinin Yapılması}

Daha müsadereye karar verilmeden önce CMK m. 123 vd. hükümleri çerçevesinde elkoyma kararı verilmesi üzerine, haczin gerçekleşmesinin mümkün olup olmadığı ele alınmalıdır. Ayrıca, elkoyma kararının mı yoksa haciz kararının mı önce olduğunun nasıl anlaşılacağı ve bu önceliğin takip için doğuracağı sonuçlar belirlenmelidir.

\section{1- Hacizde Tertip İlkesi Gereği Elkoyma Kararının Dikkate Alınması}

Elkoyma, ileride delil olarak kullanılacak veya müsadere edilecek bir eşya hakkında ilgili kişinin tasarruf yetkisini sınırlamaya yönelik bir koruma tedbiridir ${ }^{56}$. Konumuz açısından elkoyma kararının müsadere kararının yerine getirilmesine hizmet etmeye yönelik amacı önem arz etmektedir. Müsadere edilmesi muhtemel olan mal ve hakkın üzerinde tasarrufta bulunulmasını engellemek için elkoyma kararı verilebilir. Böylece, ileride müsadere kararı verildiğinde bu kararın icrası mümkün olur ${ }^{57}$. Hakkında elkoyma kararı verilen malvarlığı değeri bizzat takibin konusu olabilir veyahut takip konusu alacağı karşılamak için haczedilmiş olabilir. Böyle bir koruma tedbirine rağmen takibin ilerlemesi ve buna bağlı olarak elkoyma kararına konu malvarlığının icra dairesine teslimi veya paraya çevrilmesinin mümkün olup olmadığı tespit edilmelidir.

55 YENİSEY, Feridun/NUHOĞLU, Ayşe, Ceza Muhakemesi Hukuku, 6. Bası, Seçkin Yayınevi, Ankara, 2018, s. 391.

56 YENISEY/NUHOĞLU, 2018, s. 392.

57 ARTUK/GÖKÇEN/YENIDÜNYA/ÇAKIR, 2018, s. 446, 447. 
İcra takibine devam edilmesi noktasında elkoyma kararının hangi amaca hizmet etmek üzere verildiği çok önemlidir. Eğer ispat aracı olarak yararlı görülen bir malvarlığ1 değerinin muhafaza altına alınması isteniyorsa, bu malvarlığı değeri açısından takip işlemlerine devam edilemez. Bu durumda, icra takibi kapsamında muhafaza tedbirleri alınmasına cevaz verilmesi, ceza muhakemesinin yürütülmesini güç veya olanaksız kılabilir. Ayrıca, icra takip işlemlerine devam edilmeyecek olması, alacaklı bakımından da haksız bir durumun doğmasına sebep olmaz. Zira hakkında elkoyma kararı verilmiş mal ve hak açısından takip borçlusunun (aleyhine müsadere kararı verilmesi ihtimali bulunan kişinin) tasarrufta bulunması sınırlandırılır ${ }^{58}$. Bununla birlikte, elkoyma kararı bulunsa bile hacze karar verilebilmelidir. Aslında alacaklının zarar görmemesi için haciz kararı alınması daha isabetli olur. Şöyle ki, soruşturma ve kovuşturma için elkonulan şeyin gerekli olmadığı kanaatine varılırsa, iadeye karar verilmektedir. Buna göre, haczin uygulanmasıyla birlikte malvarlığı değerinin borçluya iadesi engellenebilir. Diğer taraftan, iadeye karar verilmesi noktasında CMK m. 131/1 hükmünde bunun resen veya talep üzerine gerçekleşeceği ifade edilmiştir. İstemde bulunma bakımından takip alacakl1s1 da bu yönde talepte bulunabilmelidir.

Elkoyma kararı gerekli kıldığı (elkonulan eşyanın delil olmasında olduğu gibi) takdirde uzunca bir süre icra takip işlemlerine devam edilemeyebilir. Böyle bir durumla karşılaşmama adına hacizde tertip ilkesine bağlı kalınarak alacaklının menfaati gözetilebilir. Hacizde tertip ilkesi gereğince, öncelikle satımı en kolay olan malvarlığı değerinin haczi yoluna gidilmelidir. Elkoyma kararı dikkate alındığında, satımın gerçekleşmesinde bu karardan ötürü bazı zorluklarla karşılaşılabilir. Bu çerçevede, hakkında elkoyma kararı verilmiş olan malvarlığı değeri en sona bırakılmalıdır. Hatta hacizde tertip ilkesi açısından elkoyma kararına konu malvarlığı değeri çekişmeli görülmelidir. Genellikle üçüncü bir kişinin lehine istihkak iddiası varsa veya daha önce başka bir haciz işlemi uygulanmışsa, çekişmeli olma durumu gerçekleşmiş olur. Bu hususta belirli bir ihtilafın giderilmesi gerekliliğine vurgu yapılmaktadır ${ }^{59}$. Elkoyma kararının akıbeti de takip işlemleri açısından aynı etkiyi doğurabilecek mahiyettedir. Dolayısıyla, müsade-

58 ARTUK/GÖKÇEN/YENIDÜNYA/ÇAKIR, 2018, s. 448.

59 ASLAN, 2005b, s. 287. 
renin gerçekleşmesine yönelik verilmiş elkoyma kararı için de aynı şey söylenebilir. Aksi hâlde, müsaderenin imkânsız kalması sebebiyle, eşdeğerin tahsil edilmesi için yeniden takip başlatılması gerekebilir. Yeniden takip yapılmasında ise ne malvarlığı hakkında müsadere kararı verilen kişinin ne de takip alacaklısının bir menfaati olabilir.

\section{2- Elkoyma Kararı ve Takibin İlerlemesine Yönelik İşlemlerin Gerçekleştirilmesi}

Müsadere kararında ilgili kişinin belirli bir malvarlığı değeri üzerindeki mülkiyet hakkı tamamen sona ermekte iken; elkoyma kararıla sadece tasarruf yetkisi kısıtlanmaktadır. Elkoymanın bu niteliği dikkate alınarak elkoyma kararına konu şey hakkında haczin mümkün olup olmadığı belirlenmelidir. Her ne kadar bir tedbir olarak elkoyma kararı verilmiş de olsa, aynı malvarlığı değeri hakkında haczin uygulanmasının mümkün olacağı kanaatindeyiz ${ }^{60}$. Haciz işlemiyle de borçluya ait olan malvarlığının takip alacağını karşılayacak kısmına elkonulması söz konusudur ${ }^{61}$. Hacizde borçlunun tasarruf yetkisi kısıtlanmakla birlikte, haczin uygulanmasındaki amaç daha farklı niteliktedir. Hacizde paraya çevrilecek malvarlığ 1 değeri üzerindeki borçlunun tasarruflarına karşı alacaklıyı korumak amacı vardır ${ }^{62}$.

Elkoyma kararı ve haciz işleminin amaçları farklı olmakla birlikte, elkoyma kararının uygulanmış olması, her ikisinin de amacının gerçekleşmesine hizmet edebilecek mahiyettedir. Çünkü elkoyma kararı verildiği takdirde hem elkoymaya konu şey hakkında tasarrufta bulunma imkânı ortadan kalkmakta hem de elkoymaya konu şey adli makamlara teslim edilmektedir. Hacizde ise haciz konusu şey (İIK m. 88/1'de geçenler hariç olmak üzere) ya borçluya ya da yediemine bırakılabilmektedir. Ceza yargısı için delil olarak kullanılacak ve hakkında elkoyma kararı verilmiş bir eşyanın ise takip borçlusuna (ceza mahkemesince aleyhine karar verilmesi ihtimali olan kişi) veya yediemine

60 CMK m. 128'de elkoyma kararının kapsamı çok geniş tutulmuştur. Hatta İ̇K m. 82 hükmüne tabi bir malvarlığı değeri hakkında da elkoyma kararı verilebilir. Haciz için ise haczi kabul görülmeyen bir kategori (İIK m. 82) oluşturmuştur. Dolayısıyla, elkoyma kararı uygulanan bir mal ve hak için dahi İ̇K ve diğer kanuni düzenlemeler tarafından getirilen sınırlandırmalara bağlı kalınarak haciz uygulanabilir.

61 ÜSTÜNDAĞ, 2004, s. 153; POSTACIOĞLU/ALTAY, 2010, s. 358, 359; KURU, 2013, s. 410.

62 POSTACIOĞLU/ALTAY, 2010, s. 360, 361. 
bırakılması belirli sakıncaları doğurabilir. Bu bakımdan, hacizli mal hakkında elkoyma kararı verildiğinde, malın elkoyma kapsamında muhafaza altına alınması daha isabetli olur. Fakat elkoyma kararı verildiği için mevcut haczin kalkacağını veya elkoyma kararı sebebiyle haczin uygulanamayacağını söylemek yanlış olur. Hatta elkoyma kararının sona ermesi ihtimali dikkate alındığında, hacze karar verilmesi suretiyle takip alacaklısinın menfaatleri korunabilir.

Buna karşın, müsaderenin gerçekleşmesine hizmet etmesi için elkoyma kararı verilmişse, haciz kapsamında muhafaza altına alma da yeterli olabilir. Çünkü bu hâlde verilen elkoyma kararı ile yalnızca borçlunun tasarruf yetkisi kısıtlanmaya çalışılır. Haciz de bu amacın gerçekleşmesi için yeterli bir hukuki araç olarak görülebilir. Lakin haczin varlığı sebebiyle elkoyma kararı için gerekli diğer işlemlerin yapılmasına gerek kalmadığı düşünülemez. Elkoyma kararının haczi koyan icra dairesine bildirilmesi ve yine sicile kayıtlı şeyler bakımından elkoyma kararının şerh edilmesini sağlanmalıdır. Şundan dolayı ki, haczin kalkmasını gerektiren hâllerde (süresinde satış istenmemesi veya takip konusu alacă̆ın ödenmesi gibi), elkoyma kararı verilmiş de olsa gerekli tedbirler alınmadığında, elkoymaya konu şey üzerinde takip borçlusu tarafından tasarrufta bulunma imkânı doğar.

Haciz işlemi, elkoyma kararından önce veya sonra olabilir. Kanaatimize göre müsadere kararı kesinleşmeden önce haciz gerçekleşirse, müsadere konusu malvarlığı değerinden takip alacaklısı tatmin edilebilmelidir. Elkoyma kararının haciz anından sonra olması hâlinde de bu görüşün savunulabileceğinden tereddüt edilmemelidir. Fakat elkoyma kararı verildikten sonra haciz gerçekleşirse, farklı görüşler dile getirilebilir. Elkoyma kararı önce olduğu için müsadere kararının kesinleşmesi ile mülkiyetin devlete geçeceği ve haczin de düşeceği savunulabilir. Diğer görüş ise elkoyma kararı ile mülkiyetin henüz devlete geçmediği ve haciz anında takip borçlusuna ait olan malvarlığı değeri ile alacaklının tatmin edileceği yönünde olabilir.

Bu görüşlerden hangisinin tercih edileceği, elkoyma kararının özel hukuk bağlamında hangi hukuki nitelikte görüleceğine göre cevaplandırılmalıdır. Müsadere davasında verilecek kararın icrasını temin etmeye yönelik olması sebebiyle elkoyma kararı 
ihtiyati tedbire benzemektedir ${ }^{63}$. Elkoyma kararının müsadere hükmünün icrasına yönelik ve geçici olmasi ${ }^{64}$, kesin hüküm teşkil etmemesi ${ }^{65}$, asıl dava ile olan sıkı ilişkisi ${ }^{66}$ gibi özellikleri dikkate alındığında HMK m. 389 vd. anlamında bir geçici koruma tedbiri olarak görülmesi mümkündür. Hatta müsadereye hizmet etmek üzere verilen elkoyma kararı, müsadere kararının kesinleşmesine kadar da etkisini gösterebilmektedir ${ }^{67}$. Elkoymanın bu özelliği göz önüne alındığında HMK m. 397/2 hükmüne benzer bir etki doğduğunu söyleyebiliriz ${ }^{68}$.

Elkoyma kararının ihtiyati tedbirden birçok noktada (belirli malvarlı̆ğ de ğerleri hakkında elkoyma kararı verilmesi için CMK m. 128 ile suç bakımından sınırlandırma getirilmesi, tamamlama merasiminin gerçekleşmesi için süre sınırlaması getirilmemiş olması gibi) farklılık arz ettiğini de belirtmeliyiz. Konumuz açısından üzerinde duracağımız husus, aslında müsadere kararının geçmişe etkili olarak hüküm ve sonuçlarını doğurup doğurmaması noktasında toplanmaktadır. Elkoyma kararı ne zaman verilmiş olursa olsun, elkoymaya konu şey hakkında devletin mülkiyet hakkı kazanması, müsadere kararının kesinleşmesi ile birlikte gerçekleşir. İhtiyati tedbir sonrasında mahkeme-

63 Hukuk uyuşmazlıklarına özgü olan "ihtiyati tedbir" ve "ihtiyati haciz” de içeriği itibariyle bir elkoymayı barındırmaktadır, bkz. YENISEY/NUHOĞLU, 2018, s. 391. Yargıtay 13. Hukuk Dairesi de vermiş olduğu bir kararda elkoyma kararını ihtiyati tedbir gibi değerlendirmiş ve tedbir kararının varlığını hukuki ayıp olarak nitelendirmiştir, bkz. Yargıtay 13. HD, E. 2016/26579, K. 2018/656, T. 25.01.2018 (Kazancı Bilişim - İçtihat Bilgi Bankası, Erişim Tarihi: 15/06/2019).

64 Kesin hukuki korumaya kadar geçecek sürede ihtiyati tedbir ile muhtemel bir tehlikeye karşı geçici bir süreliğine hukuki koruma sağlanmaktadır, bkz. ERIŞİR, Evrim, Geçici Hukukî Korumanın Türleri ve İhtiyatî Tedbir Türleri, On İki Levha Yayınevi, İstanbul, 2013, s. 142, 149; ÖZEKES, Pekcanıtez Usûl, s. 2462. Elkoyma kararı verilirken de müsaderesi gereken malvarlığı değeri hakkında geçici bir süreliğine tasarruf etme imkânı kaldırılır, bkz. YENISEY/NUHOĞLU, 2018, s. 391; ŞEN, Ersan/ERYILDIZ, Hüsnü Sefa, Elkoyma, Seçkin Yayınevi, İstanbul, 2017, s. 45.

65 Davanın görüldüğü mahkemenin ihtiyati tedbir kararı doğrultusunda bir karar vermesi zorunlu olmayıp; ihtiyati tedbir kararlarında kesin hükme (HMK m. 303) göre daha esnek bir kesinlikten bahsedilebilir, bkz. ERİşíR, 2013, s. 158-160. Elkoyma kararı verilmiş olması da mutlaka müsadere kararı verileceği anlamına gelmez, bkz. GEDİK, 2016, s. 55, 56.

66 İhtiyati tedbirde dava konusu şey ne ise doğrudan onunla ilgili bir tedbir kararı verilir, bkz. ÖZEKES, 1999, s. 61; KURU, 2013, s. 1034. Gerek eşya gerekse kazanç müsaderesinde muhakemenin konusu olan şey neyse onun hakkında elkoyma kararı verilmektedir, bkz. YENISEY/NUHOĞLU, 2018, s. 397.

67 ŞEN/ERYILDIZ, 2017, s. 44, 45; Heuchemer: Beck'scher Online-Kommentar zum Strafgesetzbuch (Hrsg.: von Heintschel-Heinegg, Bernd), 34. Ed., München, 2017 (BeckOK StGB), § 111 b kn. 20.

68 Aksi öngörülmediği sürece ihtiyati tedbir kararının etkisi, davada verilecek hükmün kesinleşmesine kadar söz konusu olur, bkz. ERIŞİR, 2013, s. 229. 
ce verilecek hükme göre ise hak sahipliği durumu geçmişe etkili olarak da tespit edilebilir ${ }^{69}$. Yani daha tedbir kararı verilmeden önce gerçek hak sahibi kim ise onun lehine olacak şekilde hüküm kurulur. Bu sebeple, ihtiyati tedbir konusu malvarlığı değerinin haczedildiği için satılması, uygulamada tedbire karar vermiş olan mahkemenin iznine bağlı görülmektedir ${ }^{70}$. Nihayetinde bu mahkemece verilecek hükme göre eğer takip borçlusunun hak sahibi olmadığg tespit edilirse, haciz işlemi ister ihtiyati tedbir kararından sonra isterse önce olsun paraya çevrime işlemi gerçekleşmemelidir. Bu farklılıktan ötürü, elkoyma kararı sonrasında gerçekleşen hacizde de müsadere kararı kesinleşinceye kadarki zaman diliminde paraya çevirme işleminin yapılabileceği ve bunun sonrasında alacaklının tatmin edilebileceği düşüncesindeyiz.

Bazı hâllerde ise bizzat takibe konuda olan malvarlığı hakkında elkoyma kararı verilmiş olabilir. Soruşturma ve kovuşturma bakımından bu malvarlığının muhafazasının gerekli olup olmadığına bakılarak bir sonuca varılmalıdır. Eğer böyle bir gereklilik yoksa CMK m. 131/1'de açıkça hükme bağlandığı üzere elkoyma konusu şeyin iade

69 Eda ve tespit davalarında mahkemece verilen hüküm ile daha önceden beri var olan bir hak veya hukuki ilişki açıklanmaktadır, bkz. TANRIVER, Süha, Medenî Usûl Hukuku (Temel Kavramlar ve İlk Derece Yargılaması), C. 1, 2. Bası, Yetkin Yayınevi, Ankara, 2018, s. 587, 588. İnşai davalar ise bazı hâllerde verilen hükümler geçmişe etkili olarak hüküm ve sonuç doğurabilmektedir, bkz. KURU, Baki/BUDAK, Ali Cem, Tespit Davaları, 2. Bası, On İki Levha Yayınevi, İstanbul, 2010, s. 57-60.

$70 \mathrm{Bu}$ hususta Yargıtay HGK'nın vermiş olduğu bir karardan hareketle icra takip işlemlerine devam edilebilmesi için elkoyma kararı vermiş olan mahkemeden izin alınması gerektiğini söylemek mümkündür. Bu kararda, hakkında ihtiyati tedbir kararı alınmış taşınmazın satımı için tedbiri koyan mahkemeden izin alınması şartı aranmıştır. Hatta tedbiri talep etmiş olan davacının satışa muvafakat göstermesinin bile yeterli olmadığı belirtilmiştir, bkz. Yargıtay HGK, E. 2017/12-1144, K. 2017/1055, T. 31.05.2017 (Kazancı Bilişim - İçtihat Bilgi Bankası, Erişim Tarihi: 15/06/2019). Buna karşın, 12. Hukuk Dairesi, tedbir kararında bu tedbirin cebri satışa engel olduğu açıkça vurgulanmamışsa, satışın (rıza ile yapılan satışlar hariç olmak üzere) gerçekleşebileceğini kabul etmektedir, bkz. Yargitay 12. HD., E. 2011/1945, K. 2011/17855, T. 03.10.2011 (Kazancı Bilişim - İçtihat Bilgi Bankası, Erişim Tarihi: 15/06/2019); 12. HD., E. 2016/22197, K. 2016/25691, T. 20.12.2016 (Kazancı Bilişim - İçtihat Bilgi Bankası, Erişim Tarihi: 15/06/2019); Yargıtay 12. HD., E. 2016/22484, K. 2017/13887, T. 09.11.2017 (Kazancı Bilişim - İçtihat Bilgi Bankası, Erişim Tarihi: 15/06/2019); 12. HD., E. 2018/11337, K. 2018/7564, T. 10.09.2018 (Kazancı Bilişim - İçtihat Bilgi Bankası, Erişim Tarihi: 15/06/2019). Cebri satışa engel olduğu açıkça belirtilmeksizin (cebri satışın dahi yapılamayacağ belirtilmeden) verilmiş bir tedbir kararı için ise farklı bir karar verilmiştir. Öyle ki, mahkemenin cevabı satışın gerçekleşemeyeceği yönünde olmasına rağmen satışın yapılması mümkündür, bkz. Yargıtay 12. HD., E. 2018/858, K. 2018/1975, T. 26.02.2018 (Kazancı Bilişim - İçtihat Bilgi Bankası, Erişim Tarihi: 15/06/2019). Yargıtay'ın bu şekildeki oluşturduğu içtihadı kabul etmek pek de olanaklı değildir. Tedbir kararında (ortada bir konkordato süreci söz konusu olmadığı sürece) icra takip işlemlerinin yapılamayacağının açıkça belirtilmiş olmasını aramak doğru bir yaklaşım değildir. Nitekim kararın verildiği tarihte bir cebri icra takibi mevcut olmadığ için ne ihtiyati tedbir talebinde bulunulurken ne de bu tedbire karar verilirken bu hususa açıkça vurgu yapılması beklenebilir. 
edilmesi gerekir. Bunun yanı sıra, müsadereye gerek kalmadığının anlaşılması hâlinde de iadeye karar verilebilir. Takibin konusu şey hakkında elkoyma kararı verildiğinde ilamlı icra takibi ya da rehnin paraya çevrilmesi yoluyla takip yapılıyorsa, kural olarak soruşturma ve kovuşturma için muhafazası gerekli olmayan mal ve hak iade edilmelidir. Çünkü takip alacaklısı ayni bir hakka (ilamlı takipte ayni hakka dayanmayan hâller hariç olmak üzere) dayanarak takip başlatmıştır. Böyle bir durumda ise "iyiniyetli" olan takip alacaklısının TCK m. 54/1 hükmünce korunması gerekeceğinden iadeye karar verilmelidir. Diğer bir ifadeyle, müsadereye karar verilmesine gerek kalmaması durumu söz konusu olur. Bu noktada, eşyanın icra dairesine verilebilmesi için elkoyma kararının kaldırılmasını ve geri verilmesini takip alacaklısı talep edebilir. Şunu da belirtmek gerekir ki, şahsi bir hakka istinaden başlatılan ilamlı takipte müsadere kararının icrası mümkün olacağı için elkoyma kararına tabi mal ve hakkın iadesi istenemez.

\section{B- Müsadere Kararına Rağmen Takip İşlemlerinin Yapılması ve Takip Bittikten Sonra Müsadereye Karar Verilmesi}

Kesinleşmiş müsadere kararına rağmen, müsadere konusu malvarlığının mülkiyetinin devlete geçtiği hususu fark edilmediği için bu malvarlığı hakkında icra takip işlemlerine devam edilmiş olabilir. Bu hâlde, yapılan takip işlemlerinin müsadere kararı sebebiyle geçerli olup olmayacağı tespit edilmelidir. Diğer taraftan, takip sona ermiş olsa da müsadere kararının uygulanması lüzumlu olabilir. Müsaderenin bu şekilde uygulanmasının ise geçmişteki takip işlemlerine etkisi ele alınmalıdır. Paraya çevirme usulüne göre bu hususun ayrı ayrı değerlendirilmesi mümkündür.

\section{1- Arttırma Yoluyla Paraya Çevirme}

Hacizli malın paraya çevrilmesinde asıl olan arttırma yoluyla paraya çevirmedir. Böyle bir durumda ihalenin iptalini ${ }^{71}$ gerektiren hususlar IIIK m. 134 kapsamında ele alınmaktadır.

71 İIK m. 134'e göre yapılan başvuruda bir cebri icra işlemi olan paraya çevirme işleminin belirli bir sakatlık sebebiyle iptal edilmesi söz konusu olmaktadır. Her ne kadar İIK m. 134'te "ihalenin feshi" terimi kullanılmış da olsa bu kurumun aslında "ihalenin iptali" olarak anlaşılması gerekmektedir, bkz. ARSLAN, 1984, s. 72, 73. Yine geçmişe etkili sonuç ortaya çıkması itibariyle ihalenin iptalinin söz konusu olduğu belirtilmiştir, bkz. ÜSTÜNDAĞ, 2004, s. 284. Her ne kadar yargı kararlarında ve öğ- 


\section{a- Takip Alacaklısı Açısından}

Müsadere kararı henüz kesinleşmemişse, hâlâ takip borçlusunun malvarlığına dâhil olan mal ve hak açısından haczin gerçekleşmesi mümkün görülmelidir. Alacakl1nın satış talebi üzerine de paraya çevirme işlemi yapılabilmelidir. Her ne kadar cebri icra işlemlerinin devam edeceğini kabul de etsek, müsadere kararının neden ileri geldiğine de bakılmalıdır. TCK m. 54/1, 2. cümle ve 54/4 hükümlerine göre verilmiş bir müsadere kararı verilmişse, paraya çevirme işleminin yapılması hiçbir şekilde mümkün olmamalıdır. Zira cebri satış gerçekleşse dahi müsadere kararı herkese karşı hüküm ve sonuç doğuracaktır.

Haciz işlemi uygulanmadan önce müsadere kararı kesinleşmişse, takip alacaklısının iyiniyetli olması, TCK m. 55/3'te öngörülen korumadan istifade etmesine imkân vermez. Müsadere kararının kesinleştiği aşamada müsadere konusu malvarlığının mülkiyeti devlete geçmiş olur. Takip alacaklısının iyiniyetli olması, haczin geçerliliğine yönelik bir hak doğurmaz. Nitekim üçüncü kişiye ait olan ve haczedilmiş bir malvarlığ 1 değeri ile takip alacaklısı tatmin edilemez. Bunun sebebi ise TMK m. 3 hükmünün uygulama alanının sınırlı olmasıdır. Yalnızca kanun ile iyiniyete hukuki sonuç bağlanan hâllerde iyiniyetin varlığına istinaden bir hak kazanılabilir ${ }^{72}$. Haciz anında iyiniyetli olmanın (takip alacaklısı bakımından) üçüncü bir kişiye ait bir malvarlığı üzerinde konulmuş haczi geçerli kılacağına yönelik kanuni bir düzenleme yoktur. Öğretide de iyiniyetli takip alacaklısı lehine gerçekleşmiş haczin geçerli görülemeyeceği belirtilmekte$\operatorname{dir}^{73}$. Buna rağmen haciz gerçekleşirse, İIKK m. 96 vd. hükümlerine göre devletin istihkak iddiasında bulunması mümkündür. Yine bu hukuka aykırılık giderilmeksizin bir şekilde müsadereye konu malvarlığı hakkında cebri satış yapılmışsa, İIK m. 134/2'ye göre ihalenin iptalini haklı kılan herhangi bir sebebe (satış talebinde bulunulmamış olması, satışın yapılacă̆ yer, gün ve saatin belirtilmemiş olması vb.) istinaden ihalenin

retide İIK m. 134'te geçen “ihalenin feshi” ifadesinin kullanımı yerleşmiş de olsa çalışmamızda bu görüşler doğrultusunda "ihalenin iptali” kavramının kullanması tercih edilmiştir.

72 OĞUZMAN, Kemal/BARLAS, Nami, Medenî Hukuk (Giriş, Kaynaklar, Temel Kavramlar), 24. Bası, Turhan Yayınevi, İstanbul, 2018, s. 253; ALTAŞ, Hüseyin, Medeni Hukuk Başlangıç Hükümleri (TMK m. 1-7), Yetkin Yayınevi, Ankara, 2014, s. 323-325.

73 ÜSTÜNDAĞ, 2004, s. 143; POSTACIOĞLU/ALTAY, 2010, s. 360; ASLAN, 2005a, s. 115 (dn. 99); KURU, 2013, s. 457. 
iptali gerçekleşirse icra veznesindeki para, takip alacaklısına ödenmemelidir (İIKK m. 134/6). Eğer İİK m. 134/2'de öngörülen süre geçmişse, ancak İ̇K m. 134/7'ye göre (malın esasl vasfinda hata gibi bir sebebe dayanarak) ihalenin iptali istenebilir ve bu talebin kabulü kararı kesinleşirse, takip alacaklısının almış olduğu bedel, buradaki ödemenin bir boyutuyla "yanlışlıkla" yapıldığı düşünülmeli ve İ̇K m. 361 hükmünün kıyasen uygulanması suretiyle ayrıca mahkeme kararına gerek kalmaksızın ${ }^{74}$ geri alınmalıdir.

Bununla birlikte, TCK m. 54/1, 2. cümle ve 54/4 hükümleri kapsamına giren bir durum varsa, müsadere kararı verilebilir. Bu karar ise her hâlükârda icra takip işlemlerini etkiler. Aslında böyle bir malvarlığının haczi mümkün olmayıp; paraya çevrilmesi de hatalıdır. Nitekim eşyanın varlığı, tek başına müsadereyi haklı kılmaktadır. Müsadereye karar verildiği takdirde ise alıcının talebi üzerine, IIIK m. 134/7'de öngörülmüşs sürelere uyulmuş olması kaydıyla, ihalenin iptaline karar verilmelidir. Takip alacaklısına ödenen bedelin geri alınmasında, yine IIIK m. 361 hükmüne kıyasen başvurulmalıdır.

TCK m. 54/1, 2. cümle ve 54/4 hükümlerinin uygulanmas1 gerekmiyorsa, icra takibi sona erdiği takdirde geçmişteki takip işlemlerini etkileyecek şekilde müsadere karar1 icra edilemez. Çünkü müsaderesi gerekli olan malvarlığı üçüncü bir kişinin mülkiyetine geçmiş olur. Müsadere kararı ise aleyhine bu karar verilen kişinin (burada takip borçlusunun) mülkiyetindeki bir malvarlığına yönelik olabilir. Öte yandan, takip alacaklısına ödenmiş bedelin eşdeğer müsaderesi kapsamında istenmesi de düşünülemez. Artık aleyhine müsadere kararı verilen kişiye karşı eşdeğer müsaderesi kapsamında takip yapılması ihtimalinden söz edilebilir.

Yine vurgulamakta fayda vardır ki, takip konusu hakkında takip alacaklısı aleyhine olacak şekilde müsadere kararı kural olarak verilmemelidir. Bu sebeple, takip alacaklısının ayni bir hakka dayanarak başlattığı takibin müsadere kararından etkilenmesi düşünülemez. Buna rağmen takip alacaklısının bu hakkı hiçe sayılarak müsadereye karar verilmiş olabilir. Mülkiyet kanun gereği devlete geçtiği için takip alacaklısı, sahip olduğu bu hakkı artık devlete karşı ileri sürebilmelidir. Yani mevcut takibin borçlu tarafında

\footnotetext{
${ }^{74}$ KURU, 2013, s. 742.
} 
devlet yer alabilmeli ve devlet aleyhine cebri icraya devam edilebilmelidir. Bununla birlikte, takip alacaklısının CMK m. 258 vd. hükümlerine göre hatalı olarak verilmiş müsadere kararı aleyhine kanun yoluna gidebileceği de kabul edilmelidir.

\section{b- Cebri Satışa İştirak Etmiş Alıcı Açısından}

Müsadere kararı kesinleştikten sonra haciz işlemi yapılamayacağı gibi satış işleminin yapılmasının da mümkün olmadığını belirtmiştik. Çünkü üçüncü bir kişinin (devletin) mülkiyetinde olan bir mal haczedilemez ve paraya çevrilemez. Yani kesinleşmiş müsadere kararı, sadece o malvarlığı ile sınırlı olmak kaydıyla icra takip işlemlerinin yapılmasına engel olur. Şayet müsadere kararı dikkate alınmaksızın satış gerçekleşmişse, bazı hâllerde ihalenin iptaline karar verilebilir. İptale karar verilir ve bu karar kesinleşirse, cebri satışa iştirak eden alıcının kazanımlarının korunup korunmayacağı ve ne ölçüde korunacağı tespit edilmelidir. Müsadere kararının hangi sebepten kaynaklandığı hususu da bu bakımdan ele alınmalıdır. Özellikle, müsadereye karar verilmesinin TCK m. 54/1, 3. cümle ve m. 54/1, 2. cümle ile m. 54/4 hükümlerine dayanması ile bu hâllerin dışındaki bir sebebe dayanmasına göre ve ihalenin iptalinin hangi süre içinde istendiğine göre bir ayrım yapılmalıdır.

\section{aa- İhale Tarihinden İtibaren Yedi Günlük Sürede İhalenin İptali}

İhalenin yapıldığı tarihten itibaren yedi günlük süre içinde menfaati olan ve İİK m. 134/2'de sayılmış sınırlı (tahdidî) belirli kişiler tarafından ihalenin iptali istenebilir. Kanun tarafından öngörülen bu süre içinde belirli sonuçlar doğar (mülkiyetin alıcıya geçmesi, yarar ve hasarın alıcıya ait olması) ve fakat bazı işlemlerin yapılması (ihaleden elde edilen bedelin alacaklyya ödenmesi, tapuya tescil için yazı yazılması) bu süre bitene kadar tehir edilir. İhale bu süre içinde iptal edilirse, ihale ile ortaya çıkmış sonuçların eski hâle iadesinde pek fazla güçlükle karşılaşılmaz. Kesinleşmiş müsadere kararı ekseninde ise istisnai olarak ihalenin iptali istenmeden de müsadere kararının icrası mümkün olabilir. Bu hâlde ise müsaderenin uygulanmasından zarar gören kişi tarafından ihalenin iptali istenebilir.

Müsadere kararı kesinleşmeden önce hacizli malın paraya çevrilmesi işlemi tamamlanmamış ise TCK m. 54/1, 3. cümle gereğince müsadereye karar verilebilir ve bu 
kararın kesinleşmesi ile haczin sonra ermesi söz konusu olur. Daha sonrasında ise paraya çevirme işleminin gerçekleşmesi mümkün olmaz. Diğer bir ifadeyle, müsadere kararı kesinleştikten sonra haciz işleminde istinaden satış yapılmamalıdır. Buna karşın, satış gerçekleşir ve İIK m. 134/2 uyarınca ihalenin iptalini haklı kılan herhangi bir sebebe (haczin geçersiz olması, ilanın istenen şartları sağlamaması vb.) dayanarak ihale tarihinden itibaren yedi gün içinde ihalenin iptali istenirse, bu talep karara bağlanana kadar tapuya yazı gönderilmez (İIK m. 134/9) ve satılan malvarlığı değeri alıcıya teslim edilemez (İ̈K m. 123/1, 2. cümle). İhalenin iptaline karar verilir ve bu karar kesinleşirse, alıcının mülkiyet hakkı sona erer (kesinleşmiş müsadere kararı sebebiyle mülkiyet devlete döner) ve icra dairesinde nemalandırılan ihale bedeli alıcıya geri verilir (İIK $\mathrm{m}$. 134/5, 2 ve 3. cümle). Müsadere kararının icra edilmesi ise iptal kararının kesinleşmesi ile mümkün hâle gelir. Sözünü ettiğimiz yedi günlük süre geçtikten sonra ise İIK m. 134/7'de geçen hâllerden biri yoksa kesinleşmiş müsadere kararına istinaden ihalenin iptali istenemez ${ }^{75}$.

İhalenin kesinleşmesinden sonra ihale bedelinin takip alacaklısına ödenebileceği hususu üzerinde de durulmalıdır. İhalenin iptalinin istenmesi için öngörülmüş yedi günlük süre içinde iptal talebinde bulunulmuşsa, bunun reddine dair kararın kesinleşmesine kadar ihale bedeli icra veznesinde tutulmalıdır. İcra veznesinde tutulan bu bedel bak1mından devletin kesinleşmiş müsadere kararına istinaden istihkak iddiasında bulunması mümkündür. Bilindiği üzere, üçüncü bir kişiye ait olan (kesinleşmiş müsadere kararı sebebiyle devlete ait olan) malvarlığı değeri sebebiyle cebri satış gerçekleştikten sonra da istihkak iddiasında bulunulabilir. Yeter ki, ihale bedeli takip alacaklısına ödenmemiş olsun $^{76}$. Bedel ödendikten sonra ise ihalenin iptalini istemek için İIKK m. 134/7'de geçen hâllerden biri (taşınmazlarda İKK m. 127'ye aykırılıktan ötürü satış ilanının tebliğ edilmemiş olması sebebi muhtemelen gerçekleşmiş olabilir) yoksa ihalenin iptali isteneme-

75 Müsadere kararı icra edilemediği için TCK m. 54/2 hükmüne göre eşdeğer müsaderesi uygulanmasına ilişkin hükümler saklıdır. Takip borçlusu (aleyhine müsadere kararı verilmiş kişi) aleyhine devletin bu düzenleme kapsamında cebri icra yoluna başvurması mümkündür.

76 ASLAN, 2005b, s. 355; KURU, 2013, s. 554. 
yecektir ${ }^{77}$. Nitekim arttırma şartnamesine (taşınmazlarda bunun bir eki olan mükellefiyetler listesi de dâhil olmak üzere) göre iktisapta bulunan alıcıya karşı, burada gösterilmemiş bir mükellefiyet ileri sürülemez ${ }^{78}$.

İstihkak iddiasında bulunamadığı için malvarlığı paraya çevrilen üçüncü kişi takip borçlusuna karşı sebepsiz zenginleşme davası açabilir ${ }^{79}$. TCK m. 54/2 ve m. 55/2 hükümleri dikkate alındığında, devletin kesinleşmiş müsadere kararına istinaden sebepsiz zenginleşme davası açması isabetsiz olur. Özel hüküm mahiyetindeki belirttiğimiz hükümlere göre müsadere kararının muhatabı aleyhine cebri icra yollarına başvurulmalıdır. Dava açılmasına gerek kalmaksızın eşdeğer müsaderesi tutarında borçlu aleyhine icra takip işlemleri zaten yapılabilecektir. Eşdeğer müsaderesi mahkeme kararına dayandığı için ilamlı icra takibi yapılabilir. Bu bağlamda, sebepsiz zenginleşme davası açılmasında hukuki menfaatin olmadığı söylenebilir.

İhalenin iptali istenmeden kesinleşmiş müsadere kararının icra edilebileceği hâller de vardır. TCK m. 54/1, 2. cümle ve 54/4 çerçevesinde verilmiş kesinleşmiş müsadere kararı herkese karşı ileri sürülebilir. Yeni malikin (alıcının) iyiniyetli iktisapta bulunduğu iddiası dahi hiçbir şekilde dinlenmez. Kamulaştırılan taşınmaz bakımından yapılan değerlendirmelere göre bu sonuca ulaşılabilir. Devir gerçekleşse de kamulaştırma kararı icra edileceği için alıcı bu durumdan etkilenir. Öğretide bu durum göz önünde tutularak kamulaştırılan taşınmaza dair ihalenin iptalinin istenebileceği belirtilmiştir ${ }^{80}$. Buna göre, TCK m. 54/1, 2. cümle ve 54/4 hükümlerine göre kesinleşmiş bir müsadere kararı varsa, alıcının iyiniyetli olup olmadığına hiç bakılmaksızın müsadere kararı icra edilebilir.

77 İstihkak iddiası görülmekte iken hacizli mal paraya çevrilirse ve bu iddia uygun görülse bile, istihkak iddiasında bulunan için ihalenin iptalini istemek mümkün değildir, bkz. KURU, 2013, s. 564.

78 PEKCANITEZ, Hakan/ATALAY, Oğuz/SUNGURTEKİN-ÖZKAN, Meral/ÖZEKES, Muhammet, İcra İflâs Hukuku, 5. Bas1, Vedat Yayınevi, İstanbul, 2018, 210, 211. Hatta cebri arttırmaya konu taşınmazın aile konutu niteliğini dahi kaybedeceği kabul edilmektedir, bkz. Yargıtay HGK, E. 2017/22935, K. 2017/1722, T. 13.12.2017 (Kazanc1 Bilişim - İçtihat Bilgi Bankası, Erişsim Tarihi: 15/06/2019).

79 ASLAN, 2005a, s. 356-359; KURU, 2013, s. 555.

80 AKYAZAN, Sitkı, Cebrî İcrada İhale ve İhalenin Feshi, Kutulmuş Matbaası, İstanbul, 1959, s. 77 ve 94; ÜSTÜNDAĞ, 2004, s. 287. Mahkeme kararına istinaden borçlunun mülkiyetinden çıkmaya ilişkin başka durumlarda da ihalenin iptali istenebilir, bkz. ARSLAN, 1984, s. 152. 
İktisapta bulunan alıcı için bundan sonra başvurulabilecek tek yol ise ihalenin iptalini istemektir.

\section{bb- Öğrenmeden İtibaren Yedi Günlük Sürede İhalenin İptali}

Eğer İIK m. 134/2'de geçen yedi günlük süre geçmişse ihalenin iptali, yalnızca İIK m. 134/7 hükmü uyarınca istenebilir. İIK m. 134/7'ye göre ihalenin iptalinin istenmesinde ise öğrenmeden itibaren işleyecek yedi günlük bir süre öngörülmüştür. Bu kapsamda süre bakımından getirilen diğer bir sınırlandırma ise ihale tarihinden itibaren bir yıl içinde ihalenin iptalinin istenebileceğidir. Bununla birlikte, yalnızca İİK m. 134/7' de zikredilen "satış ilanının tebliğ edilmemiş olması", "ihale konusu malın esaslı vasfinda hatanın sonradan öğrenilmiş olması" veya "ihaleye fesat karıştırılmış olması” sebeplerine dayanılabilir. Sırf kesinleşmiş müsadere kararı sebebiyle, İ̇K m. 134/7'deki hâllerden birinin mevcut olduğu kural olarak söylenemez. Öte yandan, TCK m. 54/1, 3. cümleye ve m. 54/4'e dayanan bir müsadere kararının doğuracağı sonuçlar, alıcının ihale konusunun esaslı vasfinda hata hâlini ileri sürmesine imkân tanıyabilir.

İIK m. 134/7 hükmü kapsamında yapılan ihalenin iptali başvurusunda, İ̈K m. 134/2'deki yedi günlük süre zaten geçmiş olur. Buna bağlı olarak, arttırma konusu şeyin mülkiyetinin devri için gerekli işlemler (taşınırın teslimi, tescil için tapuya müzekkere yazılması) yapılmış ve hatta ihale bedeli de takip alacaklısına ödenmiş olur. İhalenin iptali kararı verilir ve bu karar kesinleşirse, yine ihale öncesi duruma iade gerektiği için yapılmış işlemlerin kaldırılması da gündeme gelir. Fakat geçmişe yönelik sonuç doğurmak üzere tesis edilecek bu işlemler açısından bazı zorluklar ister istemez ortaya çı$\operatorname{kar}^{81}$. Takip alacaklısına ihale bedeli ödenmiş olduğundan dolayı, takip alacaklısından bu bedel geri alınmalıdır. İIK m. 361'in kıyasen uygulanması gerekir ve bu sebeple ayrıca bir mahkeme kararına ihtiyaç duyulmaz. Ayrıca, ihale alıcısının mülkiyet hakkı da sona erer. Bu yüzden, sicile kayıtlı mal ve hak bakımından ihaleden önceki malik adına yeniden tescil yapılmalıdır ${ }^{82}$. İhalenin iptali gerçekleştiği için ihaleden önceki durumun

81 ARSLAN, 1984, s. 187.

82 AKYAZAN, 1959, s. 96, 97; ARSLAN, 1984, s 204. 
tesisinde kesinleşmiş müsadere kararı da etkisini gösterebilir ki, bu da ihale konusunun mülkiyetinin devlete geçmesi anlamına gelir.

İhalenin iptaline karar verilmesi üzerine, alıcının ödemiş olduğu ihale bedeli daha kendisine verilmeden mülkiyetin takip borçlusuna (kesinleşmiş müsadere kararı sebebiyle devlete) geçmesi, alıcının mağdur olmasına sebebiyet verecek mahiyettedir. Burada, taşınırlarda TMK m. 989/2'ye; taşınmazlarda ise arttırma şartnamesi ve mükellefiyetler listesine istinaden TMK m. 1023'e dayanma imkânı yoktur. Aslında taşınırlarda iyiniyetli bir alıcı ödediği bedel iade edilmezse, TMK m. 989/2 gereğince alıkoyma hakkına dayanabilmektedir ${ }^{83}$. Cebri arttırmada ise alıcı lehine bu şekilde bir alıkoyma hakkından bahsedilemez.

TCK m. 55/3 gereğince iyiniyetli olması hâlinde alıcının korunabileceği düşünülebilir. Her ne kadar alıcı iyiniyetli de olsa, ihalenin iptalinde iyiniyet kurallarına dayanılamamaktadır. Dolayısıyla, ihalenin iptali kararının kesinleşmesi üzerine müsadere kararının icrası, alıcının iyiniyetli olup olmadığına bakılmaksızın mümkündür. Bununla birlikte, ister İIK m. 134/2 isterse İ̈K m. 134/7 kapsamında ihalenin iptaline karar verilsin, alıcı açısından TMK m. 993 ve 994 hükümleri uygulanabilir ${ }^{84}$.

\section{cc- İhalenin İptalini İsteme Sürelerinin Geçmiş Olması}

İhalenin iptali için öngörülmüşs sürelerin geçmesi, ihalenin kesinleşmesi sonucunu doğurur. İlk olarak, İİK m. 134/2'ye göre yedi gün içinde ihalenin iptali istenmezse veya ihalenin iptali talebi reddedilir ve bu ret kararı kesinleşirse, paraya çevirme işlemi kesinleşmiş olur ${ }^{85}$. Diğer bir hâl ise ihale tarihinden itibaren bir yıllık sürenin de geçmesidir. $\mathrm{Bu}$ süre hak düşürücü süre olduğu için ihalenin iptalinin talep edilmesi artık

83 TMK m. 989 hükmü uyarınca, açık arttırmadan bir mal hakkında iktisapta bulunan kişi, iyiniyetli olması kaydıyla kendisine ödediği bedel verilmediği sürece satın aldığını iadeden imtina edebilir, bkz. ALTAŞ, 2014, s. 338.

84 ARSLAN, 1984, s. 204.

85 KURU, 2013, s. 717, 718. İhalenin iptali için öngörülmüş süre hak düşürücü süre olup; bu sürenin geçip geçmediği mahkemece resen dikkate alınır. Süre geçmişse esasa girmeden başvurunun reddine karar verilmelidir, bkz. MUŞUL, Timuçin, İcra ve İflâs Hukukunda İhale ve İhalenin Feshi, Adalet Yayınevi, Ankara, 2016, s. 447, 448. 
mümkün olmaz ${ }^{86}$. Aslında ihalenin iptali söz konusu olmadığı için müsadere kararı kural olarak icra edilmemelidir. Hatta bu hâlde müsadere kararının uygulanması TCK m. 55/3 ile bağdaştırılamaz. Fakat müsadereye karar verilmesine malvarlığının varlığı başlı başına sebep teşkil ediyorsa farkı bir sonuç doğabilir. TCK m. 54/1, 3. cümle ve m. 54/4 uyarınca kimin elinde olursa olsun belirli bir malvarlığı müsadere tabi tutulabilir. Buna bağlı olarak da cebri satışa iştirak eden kişi, müsadere kararı sebebiyle ihalenin iptalini talep etmek zorunda kalır. Satışa konu şeyde hukuki bir ayıp söz konusu olduğu için ihalenin iptali istenebilir. Müsadere kararı sebebiyle, İIK m. 134/7 hükmü gereğince satılan malın esaslı vasfinda hataya dayanmak mümkündür ${ }^{87}$. İhalenin iptaline karar verilirse, normalde alıcının mülkiyet hakkı sona erer ve bu hak takip borçlusuna geri döner ${ }^{88}$. Kesinleşmiş müsadere kararı sebebiyle mülkiyetin devlete geçmesi söz konusu olduğu için ihalenin iptali kararı kesinleşirse, mülkiyetin takip borçlusuna geri dönmesinden söz edilemez.

Yukarıdaki duruma ihalenin iptalini isteme süresi geçmişse artık ihalenin iptali istenememelidir ${ }^{89}$. Usulsüz de olsa ihale bu şekilde kesinleştiği için ihale bedelinin takip alacaklısından talep edilemeyeceği kabul edilmelidir. Kanaatimizce, iktisapta bulunan alıcının İIKK m. 5 hükmüne göre devlet aleyhine tazminat davası açması mümkün gö-

86 ARSLAN, 1984, s. 180; KURU, 2013, s. 711. Kamu düzenine aykırılık teşkil edecek ağırlıkta bir hata veya noksanlık bulunsa bile, ihaleye olan güveni korumak adına, İ̇K m. 134/7'de öngörülmüş bir y1llık sürenin aşılması mümkün değildir, bkz. ARSLAN, 1984 s. 179, 180. Kesinleşmiş müsadere kararına rağmen ihalenin yapılması da aslında kamu düzenine aykırıdır. Fakat ihaleye güven ilkesinin korunması adına devletin ihale tarihinden itibaren yedi gün içinde ihalenin iptalini istemesi gerekir. Bunun sebebi ise kesinleşmiş müsadere kararının tek başına devlet açısından İ̇K m. 134/7'deki hâllerden birine dayanılmasına imkân vermemesidir.

87 İhale anından önce müsadere kararı verilmemiş olduğu için ihalenin iptalinin istenemeyeceği düşünülebilir. Lakin ihalenin yapıldığı anda da ihale konusunun müsadere edileceği kesin olduğu için bu düşünce isabetli görülemez. Müsadere kararı ile sadece daha önceki bir aşamada mevcut olan iptal sebebi bu karar ile fark edilmektedir. Hatta müsadereye hiç karar verilmese de bu durum fark edildiği takdirde, süresi içinde olması kaydıyla ihalenin iptali istenebilmelidir.

88 ARSLAN, 1984, s. 204; ÜSTÜNDAĞ, 2004, s. 284; KURU, 2013, s. 723, 724; YILDIRIM/DERENYILDIRIM, 2016, s. 258, 259.

89 PEKCANITEZ/ATALAY/SUNGURTEKIN-ÖZKAN/ÖZEKES, 2018, s. 221. Borçlunun mülkiyetinden çıkmış (kamulaştırma gibi) malvarlığı bakımından ihale konusunun mevcut olmadığının tespitinin istenebileceği de belirtilmektedir. Buna göre, yapılacak şikâyet başvurusu süresizdir, bkz. BULUR, Alper, "İcra ve İflâs Hukukunda "Fesat Karıştırma" ve "Malın Esaslı Niteliklerinde Hata" ya Dayanan İhalenin Feshi Nedenleri”, Gazi Üniversitesi Hukuk Fakültesi Dergisi, Y11: 2017, Cilt: XI, Say1: 1-2, s. 66. 
rülmelidir ${ }^{90}$. İhale konusu malvarlığı değerinin müsadereye konu olup olmadığ 1 , ihaleye hazırlık sürecinde cebri icra organı tarafından mutlaka araştırılmalıdır. İIK m. 5'e göre sorumluluk kusur sorumluluğu olduğundan ${ }^{91}$ ötürü, kusurun atfedilemeyeceği hâllerde ise devletin tazminat sorumluluğuna gidilemez. İIK m. 7 hükmü uyarınca tazminat davas1, zararın öğrenildiği günden itibaren bir yıl ve her hâlde fiilin gerçekleşmesinden itibaren on yıl içinde açılmalıdır. Zararın gerçekleşme tarihi olarak ise ihale günü kabul edilmemelidir. Nitekim müsadere kararı verilmeden önceki bir aşamada zarardan bahsedilemez. Hatta müsadere kararının hüküm ve sonuçlarını doğurması kesinleşmeye bağlı olduğu için kesinleşme tarihi esas alınmalıdır. Bu yüzden, müsadere kararının kesinleştiği tarihten itibaren zamanaşımı süresi işlemeye başlamalıdır.

\section{2- Pazarlık Yoluyla Paraya Çevirme}

Cebri icrada hacizli malın paraya çevrilmesinde asıl kural açık artırma iken, istisnai bazı hâllerde (İIK m. 119) pazarlık suretiyle paraya çevirme gerçekleşebilir. Bu yöntemle paraya çevrilen bir mal veya hak da aynı zamanda müsadere kararının konusu olabilir. Yine hangi menfaate öncelik tanınacağını belirleyebilmek için pazarlık yoluyla satışta mülkiyetin alıcıya hangi anda geçeceği belirlenmelidir. Bu hususta satım anında mülkiyetin geçeceği görüşü ${ }^{92}$ ile genel kurallara göre mülkiyetin geçeceğii ${ }^{93}$ şeklinde farklı görüşler temsil edilmektedir. Mülkiyetin geçtiği andan sonraki bir aşamada ise müsadere karının kesinleşmesi, pazarlık yolu ile satım yönündeki icra takip işleminin geçerliliği etkilememelidir. Şayet satış yapılmadan önce müsadere kararı kesinleşirse

90 İhalenin iptalini isteme süresi geçmeden önce İIKK m. 5 hükmünce dava açılırsa, alıcının birlikte kusurunun varlığından söz edilebilir. Nitekim Yargıtay’a göre zararı gidermeye yönelik hukuki yolları tüketmeyen kişinin birlikte kusuru vardır ve tazminattan indirim yapılmalıdır, bkz. Yargıtay 4. HD, E. 2010/8772, K. 2011/10378, T. 12.10.2011 (Kazancı Bilişim - İçtihat Bilgi Bankası, Erişim Tarihi: 15/06/2019).

91 YILMAZ, 2016, s. 53, 54.

92 ERTURGUT, Mine, İcra ve İflâs Hukukunda Menkullerin Paraya Çevrilmesi, Yetkin Yayınevi, Ankara, 2000, s. 190; ÖZMUMCU, Seda, Cebri İcra Hukukunda Pazarlık Suretiyle Satış, Vedat Yayınevi, İstanbul, 2005, s. 147. Hatta pazarlık yoluyla satışın TMK m. 705/2 kapsamında “cebrî ic$r a$ " işlemine dayanması sebebiyle, pazarlık suretiyle taşınmazın paraya çevrilmesinde bile tescilden önce mülkiyet alıcıya geçmelidir, bkz. ÖZMUMCU, 2005, s. 143, 147 ve 148.

93 Pazarlık yoluyla satışta taşınır bir malın mülkiyetinin geçmesi için zilyetliğinin devrinin gerektiği kabul edilmektedir, bkz. KURU, 2013, s. 629. Taşınmazlarda ise tapu siciline tescil yapılmalıdır, bkz. KURU, Baki, İcra ve İflas Hukuku, 3. Bası, C. IV, Seçkin Yayınevi, Ankara, 1997, s. 3299. 
artık üçüncü bir kişiye (devlete) ait taşınır malın satımı gerçekleşmiş olur. Devlet, sırf bu sebepten ötürü şikâyet yoluna başvuramamalı ve fakat henüz ödenmemiş satım bedeli üzerinde istihkak iddiasında bulunabilmelidir. Çünkü bir takip hukuku işlemi olan pazarlık yoluyla satışa niteliğine uygun düştüğü ölçüde açık arttırma ile satışa ilişkin hükümler uygulanabilmektedir ${ }^{94}$. Buna karşın, farklı bir sebepten ötürü şikâyet yoluna gidilirse satış işlemi iptal edilebilirr ${ }^{95}$.

Şikâyet başvurusu neticesinde pazarlık suretiyle satışın iptaline karar verildiğinde ortaya çıkacak sonuçlar geçmişe etkili olur ${ }^{96}$. Buna bağlı olarak, alıcının ödediği ve takip alacaklısına verilmiş bedel geri alınmalıdır. Alıcıya verilen mal ve hakkın ise geri alınması da aynı kapsamda gerçekleşebilir. Yerine göre teslim edilen malın geri alınmaS1 ve hatta tapu kaydının düzeltilmesi söz konusu olur ${ }^{97}$. Dolayısıyla, ayrı bir dava açmaya gerek kalmaksızın, pazarlık yoluyla paraya çevirme işleminin iptali kararının kesinleşmesi üzerine, İIK m. 361'in kıyasen uygulanması suretiyle iade gerçekleşmelidir. Netice itibariyle, kesinleşmiş müsadere kararı dikkate alındığında satışın iptali sonrasında satım konusu malvarlığının mülkiyeti devlete ait olur. Şayet kimin elinde olursa olsun TCK m. 54/1, 3. cümle ve m. 54/4 uyarınca müsaderesi gereken bir malvarlığ1 değeri pazarlık yoluyla paraya çevrilmişse, müsadere kararı icra edileceği için şikâyet yoluna başvurulabilmelidir. Esaslı vasıfta hataya istinaden satımdan itibaren yedi gün içinde şikâyet yoluna başvurulması hususunda tereddüt edilemez. Fakat İIKK m. 134/7'nin pazarlık yoluyla satışta uygulanamayacağı yönündeki görüşe ${ }^{98}$ rağmen alıc1,

94 ARSLAN, 1984, s. 65-67; ERTURGUT, 2000, s. 167-169; ÖZMUMCU, 2005, s. 73, 77.

95 ARSLAN, 1984, s. 63, 65; KURU, 1997, s. 3301; Hatalı olarak yapılmış pazarlık yolu ile satış işlemine karşı şikâyet yoluna başvurulabilir, bkz. PEKCANITEZ/ATALAY/SUNGURTEKİNÖZKAN/ÖZEKES, 2018, s. 207. Yargıtay 12. HD de vermiş olduğu bir kararda pazarlık yolu ile satışta kanuna aykırılığın şikâyet yoluyla ileri sürülebileceğini kabul etmiştir, bkz. Yargıtay 12. HD, E. 2016/13183, K. 2017/4058, T. 16.03.2017 (Kazancı Bilişim - İçtihat Bilgi Bankası, Erişim Tarihi: 12/01/2019). İIK m. 134'e göre başvuru yapılmamasının sebebi ise ihale olmadığ1 için bu hükmün uygulanamayacak olmasıdır, bkz. KURU, 2013, s. 630; YILMAZ, Ejder, İcra ve İflâs Kanunu Şerhi, Yetkin Yayınevi, Ankara, 2016, s. 649.

96 ÖZMUMCU, 2005, s. 205.

97 KURU, 1997, s. 3302; ÖZMUMCU, 2005, s. 206.

98 KURU, 1997, s. 3302. Kamu düzenine aykırılık mevcut olduğu takdirde ise şikâyetin süreye tabi olmadığ1 görüşü benimsenmiştir, bkz. KURU, 1997, s. 3301 (dn. 26). 
satımdan itibaren bir yıl içinde de şikâyet yoluna gidebilmelidir ${ }^{99}$. Azami süre olan bu bir yıllık süreden sonra ise alıcı, bu hususta kusurun varlığı kaydıyla İIKK m. 5 çerçevesinde tazminat talep edebilir.

\section{III- Müsadere Konu Malvarlığının Bedelinin Tahsil Edilmesi}

İcra takibi çerçevesinde müsaderesi gereken malvarlığı değerinin alacaklıya verilmesi veya paraya çevrilmesi, müsadere kararının icrasına engel olur. Bundan sonra müsadere konusunun değerinde bir para alacağının devlet lehine tahsili lüzumlu hâle gelir. Eşdeğer müsaderesine konu bedelin tahsilinde ise devletin cebri icra yoluna başvurması şarttır. Zira aleyhine eşdeğer müsaderesi kararı verilmiş kişinin işlenmiş suç ile hiçbir alakası olmayan belirli bir malvarlığının doğrudan devlete intikal etmesi şeklinde bir uygulama düşünülemez.

\section{A- Başka Takip Alacaklarına Ödeme Yapma Gerekliliği}

Hakkında müsadere kararı verilmiş ve icra takibi çerçevesinde paraya çevrilmiş malvarlığından elde edilen para ile öncelikle takip alacaklısına ödeme yapılır. Ödeme yapıldıktan sonra eğer varsa kalan kısmın devlete ödenmesi gerekir. Fakat devlete ödeme yapılabilmesi için müsadere kararının kesinleşmesi beklenmelidir. Müsadere kararının kesinleşmesine kadar başka bir alacaktan dolayı da icra takibi yapılmakta olabilir. Paraya çevrilmesine rağmen müsadere kararı kesinleşmediği için devlete ödenemeyen icra veznesindeki paranın bu takip sebebiyle haczedilmesi ihtimali doğabilir. Çünkü müsadere kararı kesinleşmediği için paranın devlete ödenmesi mümkün değildir. Yine müsadere karar kesinleşmediği için bu para hâlâ aleyhine müsadere kararı verilmiş kişiye aittir. Takip alacaklısına ödeme yapılması sonrası icra veznesindeki artan paranın takip borçlusuna iadesine ise elkoyma kararı engel teşkil edebilir.

Paraya çevirme işlemi sonrasında icraya konulan alacaktan dolayı da henüz devletin mülkiyetine geçmemiş olan icra veznesindeki para haczedilebilmelidir. İcra veznesinde bulunan ve bu aşamada borçluya ait olan paranın haczi ise o borçlu aleyhine baş-

99 ARSLAN, 1984, s. 66; ÖZMUMCU, 2005, s. 202. 
latılacak bir takipte İIKK m. 89'a göre gerçekleşebilir. Kaldı ki, arta kalan paranın mülkiyetinin takip borçlusuna ait olup olmadığı henüz kesin olarak belli değildir. Ayrıca, icra veznesindeki para hakkında elkoyma kararı bulunsa da sonraki takip alacaklılarına icra veznesindeki paradan ödeme yapılabilmelidir.

\section{B- Müsadere Bedelinin Tahsilinde İzlenecek Usul}

İcra takibi neticesinde alacaklıya ödeme yapılması sebebiyle tahsil edilemeyen k1sım, eşdeğer müsaderesine konu olur. Bu durum, TCK m. 54/2 ve m. 55/2'de açıkça ifade edilmiştir. İcra takibi neticesinde müsaderenin icrası imkânsız hâle gelirse, müsadere edilmesi muhtemel olan şeyin değeri kadar para tutarı için eşdeğer müsaderesi gerçekleşir. Aleyhine müsadere kararı verilmiş kişiye ait olan başka mal ve haklara müracaat edilirken bunların suç ile herhangi bir bağ içinde olması da doğal olarak aranmaz. $\mathrm{Bu}$ şekilde ilgili kişinin diğer malvarlığı değerlerinden müsadere bedelinin tahsilinde cebri icra yolu ile takip yapılmalıdır. Çünkü ilgili kişiye ait başka malvarlığı değerlerinin müsadere edilmesi şeklinde bir uygulama mümkün değildir ${ }^{100}$.

Eşdeğer müsaderesi hakkında Suç Eşyası Yön. m. 18/1 - (e)'de müsadereye karar verilirken müsaderenin imkânsız kılınması ihtimali gözetilerek bir düzenleme yapılmıştır. Buna göre, müsadereye karar verilirken eşdeğerin tahsil edilebilmesi için bilirkişiye müracaat edilmelidir ${ }^{101}$. Bilirkişi incelemesi sonrasında mahkeme veya hâkim tarafından eşdeğer müsaderesine karar verilebilir. Bunun yanı sıra, müsadereye karar verildiği tarihte eşdeğer müsaderesini gerektiren bir durum olmayabilir. Sonradan eşdeğer müsaderesini haklı kılan bir sebep gerçekleştiğinde ise müsadere kararının icrasında tereddüt yaşanır. Bu noktada, müsadereye karar vermiş mahkemenin veya hâkimin eşdeğer belirlemek üzere yeniden bir karar vermesi mümkün görülmelidir.

Suç Eşyası Yön. m. 18/1 - (e) hükmünde, müsadere bedelinin 6183 sayılı K. hükümlerine göre tahsil edilebileceği ifade edilmiştir. Oysaki cebri icra faaliyetinin temel

$100 \mathrm{Bu}$ hususta parası olmayan bir failin müsadere konusu şey değerinde başka bir eşyasının müsadere edilmesini sağlamanın kural olarak mümkün olmadığı belirtilmiştir, bkz. SOYGÜT-ARSLAN, 2014, s. 453. Kanaatimizce, faile ait başka bir malvarlığı değerinin müsadere edilemeyeceği mutlak bir durum olarak görülmelidir. Eşdeğerin tahsilinde, borçluya ait diğer mal ve haklar bakımından cebri icra yolunu tüketmekten başka çare olmadığı kabul edilmelidir.

101 SOYGÜT-ARSLAN, 2014, s. 452, 453. 
haklar ile olan doğrudan ilişkisi sebebiyle kanunilik ilkesi benimsenmiştir. Bu ilke uyarınca, cebri icraya yönelik yollar ve bu yollar içindeki usul ve esaslar kanun ile belirlenmiş olmalıdır ${ }^{102}$. Kanaatimizce, belirli bir alacağın hangi takip yoluyla tahsil edileceği de kanunilik ilkesi doğrultusunda değerlendirilmelidir. Nitekim başvurulacak takip türüne göre uygulanacak takip işlemleri farklılık arz edebilmektedir. Dolayısıyla, ileri sürülen alacağın hangi takip yoluna tabi olduğu kanuni bir düzenleme ile belirlenmelidir. İIKK m. 47'de de belirtildiği üzere, devlet alacakları bakımından sadece kanuni düzenlemelerin saklı kaldığı belirtilmiştir. Yani yönetmelik gibi bir düzenleyici işlem ile bir alacağa uygulanacak takip usul ve esasları belirlenmemelidir. Dolayısıyla, belirli bir para alacağının 6183 sayılı K. hükümleri ile öngörülen özel bir takip yoluna tabi tutulması istendiğinde de bunun kanun ile düzenlenmiş olması gerekir. Bu itibarla ifade edilmelidir ki, müsadere bedelinin 6183 sayılı K. hükümlerine tabi tutulacağının yönetmelik ile öngörülmesi, kanunilik ilkesine aykırıdır. O hâlde, eşdeğerin tahsilinde 6183 sayılı K. m. 1 anlamına bir alacak olmadığı dikkate alınmalı ve 6183 sayılı K. hükümlerinde öngörülmüş usullere başvurulamamalıdır. Eşdeğer müsaderesi ilama bağlı bir alacak olduğu için bu bedelin tahsilinde İİK m. 32'ye göre icra takibi yapılmalıdır. Fakat bu hâlde paraya çevirme usulünde İIKK m. 48 hükmü gereğince İİK m. 106 vd. hükümlerine başvurulamaz.

Eşdeğer müsaderesinin icra edilmesini temin etmek üzere elkoyma kararı verilip verilemeyeceği hususu üzerinde de durulmalıdır. Şayet elkoyma kararı verilebilirse, elkoymanın bu şeklinin ihtiyati haciz gibi işlev gördüğü söylenebilir. İhtiyati hacizde belirli bir alacak için bir borçlunun paraya çevrilebilir mal ve hakları (taraflar arasındaki uyuşmazlığın konusu olmayan) üzerindeki tasarruf yetkisi kısıtlanmaktadır ${ }^{103}$. Eşdeğer müsaderesi söz konusu olduğunda da devlet (alacaklı), belirli bir para alacağı (eşdeğer müsaderesi kapsamında tespit edilen miktar) sebebiyle, müsadere kararının muhatabının (borçlunun) diğer mal ve haklarından (müsadereye karar verilmesine sebep olan suç ile hiçbir bă̆ı olmayan) alacağını tahsil etmeye çalışmaktadır. Bu bağlam-

102 ÖZEKES, Muhammet, İcra Hukukunda Temel Haklar ve İlkeler, Adalet Yayınevi, Ankara, 2009, s. 90; PEKCANITEZ/ATALAY/SUNGURTEKIN-ÖZKAN/ÖZEKES, 2018, s. 28.

103 ÖZEKES, 2009, s. 12, 13; ERİȘİR, 2013, s. 229; KURU, 2013, s. 1034; YILMAZ, 2016, s. 1089. 
da elkoyma kararı verilebilirse, aleyhine müsadere kararı verilmiş kişinin kendi mal ve hakları üzerindeki tasarrufları kısıtlandığından, ihtiyati hacze benzer bir etki meydana gelmiş olur.

Alman hukukunda ACUK (Alman Ceza Usul Kanunu) m. 111c hükmü uyarınca eşdeğer müsaderesinin gerçekleşmesine hizmet etmek üzere elkoyma kararı verilebilmektedir. Orantılılık ilkesi açısından bu şekildeki elkoyma kararında lüzumlu olma şartı aranmaktadır. İleride gerçekleşecek cebri icranın mümkün olmaması veya önemli ölçüde zorlaşacak olması ihtimali varsa bu şart da gerçekleşmiş olur ${ }^{104}$. Elkoymanın bu şekilde gerçekleşmesinde, müsadere kararının muhatabının diğer mal ve hakları elkoymaya tabi tutulur ${ }^{105}$. Bu bakımdan, ihtiyati hacze ilişkin hükümler kapsamında görülebilecek bir elkoyma kararı söz konusu olur ${ }^{106}$. İsviçre hukukunda ise eşdeğer müsaderesi söz konusu olduğunda ilgilinin malvarlığına elkonulabileceği, İCK (İsviçre Ceza Kanunu) m. 71/3'te açıkça hükme bağlanmıştır. Eşdeğer müsaderesi için verilen elkoyma kararı ile birlikte devlet lehine olacak şekilde ihtiyati hacze benzer bir etki doğmaktadır. Eşdeğerin tahsilinde ise takip hukuku kapsamında ileri sürülen diğer alacaklar ile eşit muameleye tabi tutulma söz konusu olmalıdır ${ }^{107}$.

Türk hukukunda ise Alman ve İsviçre hukukunda olduğu gibi eşdeğer müsaderesi kapsamında elkoyma kararı verilmesi mümkün değildir. Gerek CMK m. 123/1 gerekse CMK m. 128/1 hükümleri ile müsadere kararları verilebilecek hâller suç ile bağlantılı eşyalara özgülenmiştir ${ }^{108}$. Eşdeğer müsaderesinde ise muhatabın suç ile bir ilişkisi olmayan mal ve haklarına başvurulmaktadır. Aslında elkoyma kararı verilerek ilgili kişinin suç ile bağlantısı olmayan malvarlığı değerlerini temlik etmesinin önüne kolaylıkla geçilebilirdi. Bu bağlamda, söz konusu bu hususun kanuni bir düzenlemeye bağlanma-

104 Heuchemer: Beck'scher Online-Kommentar zum Strafgesetzbuch (Hrsg.: von Heintschel-Heinegg, Bernd), 34. Ed., München, 2017 (BeckOK StGB), § 111e kn. 9.

105 Heuchemer: Beck'scher Online-Kommentar zum Strafgesetzbuch (Hrsg.: von Heintschel-Heinegg, Bernd), 34. Ed., München, 2017 (BeckOK StGB), § 111e kn. 2.

106 Heuchemer: Beck'scher Online-Kommentar zum Strafgesetzbuch (Hrsg.: von Heintschel-Heinegg, Bernd), 34. Ed., München, 2017 (BeckOK StGB), § 111e kn. 1.

107 JEAN-RICHARD-dit-BRESSEL, Marc, “Konkorsprivileg durch Strafrecht?”, Schweizerische Zeitschrift für Zivilprozess- und Zwangsvollstreckungsrecht, Y1l: 2017, Heft: 41, s. 76.

108 YENISEY/NUHOĞLU, 2018, s. 397. 
mış olmasının bir eksiklik olduğunu belirtmeliyiz ${ }^{109}$. Elkoyma kararının bu gibi hâllerde de verilebileceği kabul edilerek elkoyma kararının ihtiyati haciz kararı gibi işlev görmesi temin edilebilir.

Eşdeğer müsaderesi sebebiyle ihtiyati haczin nasıl gerçekleşeceği, Suç Eşyası Yön. m. 18/1 - (e) hükmüne göre 6183 sayılı K. m. 13 vd. hükümleri çerçevesinde belirlenebilir. Fakat görüşümüze göre Suç Eşyası Yön. m. 18/1 - (e) hükmünün kanunilik ilkesine aykırı olması sebebiyle, bu durumda 6183 sayılı K. m. 13 vd. hükümlerinin uygulanma kabiliyeti yoktur. Dolayısıyla, eşdeğerin tahsili için genel hükümler (İIK m. $257 \mathrm{vd}$.) çerçevesinde ihtiyati haciz uygulanabilir.

\section{SONUÇ}

Gerek müsadere kararı gerekse cebri icra takibi belirli bir kişinin mülkiyetindeki mal ve haklara yönelik kurumlardır. Öyle hâller söz konusu olabilir ki hakkında müsadere kararı verilmiş belirli bir mal ve hak, aynı zamanda icra takibinde hacze konu olabilir veya icra takibinin bizzat konusu olabilir. $\mathrm{Bu}$ gibi durumlarda müsadere kararının uygulanması yönündeki menfaate mi yoksa takip alacaklısının tatmin edilmesine yönelik menfaate mi öncelik tanınacağının tespiti gerekir. Müsadere kararına karşın icra takip işlemlerine devam edilmesi, bu kararın hüküm ve sonuç doğurduğu ana bağlıdır. Çünkü müsadere kararı sonrasında mülkiyetin devlete geçmesi, bu kararın kesinleşmesi ile mümkün olur. Mülkiyetin devlete geçtiği andan itibaren ise icra takibinde üçüncü bir kişiye ait bir mal ve hak hakkında işlem yapılması durumu ile karşılaşılır.

Müsadere kararı kesinleşmeden önce tatbik edilmiş bir haciz işlemi bu karara istinaden geçerliliğini korumalıdır. Takip alacaklısının alacağını teminat altına almaya yönelik bir işlem olan haciz işlemini geçerli görmek, mülkiyet hakkı kapsamında olan alacak hakkının gözetilmesini sağlar. Bununla birlikte, öyle bazı hâller söz konusu olabilir ki haciz işlemine karşın müsadere kararının icra edilmesi lüzumu doğar. TCK m. 54/1, 2. cümle ve m. 54/4 hükümlerine göre müsadere kararı verilmesi eşyanın varlığına bağ-

109 DURSUN, İsmail, “Ceza Muhakemesi Hukukunda Taşınmazlara, Hak ve Alacaklara Elkoyma”, Prof. Dr. Mehmet Akif Aydın'a Armağan, Ankara, 2015, s. 543. 
1ıdır. Bu eşya, her kimin elinde olursa olsun müsadere edilmesi gereken bir eşya mahiyetindedir. Bu sebeple, takip alacaklısının bu nitelikteki bir malvarlığından tatmin edilmesi düşünülemez. Takibin konusunu oluşturan malvarlığı değeri hakkında ise TCK m. 55/3 kapsamında iyiniyetli olan takip alacaklısı aleyhine müsadere kararı verilmesi zaten mümkün değildir.

Müsadere kararı kesinleştikten sonra ise bir icra takip işlemi olan haciz işlemi uygulanamaz. Aksi hâlde, İIK m. 96 vd. hükümlerine göre devletin istihkak iddiasında bulunması kaçınılmazdır. Nitekim müsadere kararı kesinleştikten sonra artık üçüncü bir kişiye ait olan bir mal ve hakkın haczi yoluna gidilmiş olur. Takip alacaklısının müsadere sebebiyle mülkiyetin devlete geçmiş olduğunu bilmemesi (iyiniyetli olması), bu bakımdan önemsizdir. Buna rağmen haczin uygulanması ve müsadere edilmiş malvarlığının paraya çevrilmesi gibi istenmeyen durumlar yaşanabilir. Paraya çevirme bedeli takip alacaklısına henüz ödenmemişse, devletin bu bedel üzerinde istihkak iddiasında bulunması mümkündür. Eğer ödeme gerçekleşmişse yalnızca cebri satımın iptaline karar verilirse, müsadere edilmiş malvarlığının mülkiyetinin devlete dönmesi söz konusu olabilir. Yine bu iptale bağlı olarak alıcının ödediği bedel takip alacaklısından geri alınabilir.

Her ne kadar müsadere kararı dikkate alınmadan gerçekleşmiş cebri satımı korumak gerekli de olsa, TCK m. 54/1, 2. cümle ve 54/4 hükümlerine göre verilmiş bir müsadere kararı her hâlükârda hüküm ve sonuçlarını doğurabilir. Bu hâlde, cebri satıma iştirak eden alıcı için İ̇K m. 134/7'ye göre cebri satımın iptalini isteme hakkı doğar. Çünkü paraya çevrilmiş mal ve hakkın esaslı vasfında bir hata mevcut olur. İptal için ise mevzuatta geçen sürelere bağlı kalınmalıdır. Eğer bu süreler geçmiş ise müsadere kararından zarar gören alıcı, İIK m. 5'e göre bir kusurun varlığı kaydıyla devlet aleyhine tazminat davası açabilir.

Müsadere kararı icra edilemezse, müsadere konusu değerinde bir para alacağının devlet lehine tahsili ihtiyacı doğar. Suç Eşyası Yön. m. 18/1 - (e)'de eşdeğer müsaderesi kapsamında bu bedelin tahsil edilebilmesinde 6183 sayılı K. hükümlerinin uygulanacağı belirtilmiştir. Takip usul ve esaslarının sadece kanun ile belirlenebileceği ilkesi gereğince bu yönetmelik hükmü uygulanamamalıdır. Dolayısıyla, bir mahkeme kararına dayanan eşdeğer müsaderesine konu bedelin tahsili için İİK m. 32 kapsamında icra takibi 
yapılmalıdır. $\mathrm{Bu}$ bedelin tahsili öncesinde bir ihtiyati haciz kararı verilebileceğinden ise şüphe edilemez. Fakat bu şekilde bir etkinin doğması adına elkoyma kararı verilmesine imkân tanımak daha isabetli olabilir. Türk hukukunda elkoymaya ilişkin hükümler ise maalesef buna cevaz vermemektedir. Olması gereken hukuk bakımından ise ihtiyati haciz etkisi doğuracak şekilde de elkoyma kararı verilebilmesi öngörülmelidir. 


\section{KAYNAKÇA}

AKBULUT, Berrin, Ceza Hukuku (Genel Hükümler), 5. Bası, Seçkin Yayınevi, Ankara, 2018.

AKCAN, Recep, Hacze İştirak, Seçkin Yayınevi, Ankara, 2005.

AKİL, Cenk, Borçlunun Üçüncü Kişilerdeki Mal ve Alacaklarının Haczi, Yetkin Yayınevi, Ankara, 2013.

AKYAZAN, Sıtkı, Cebrî İcrada İhale ve İhalenin Feshi, Kutulmuş Matbaası, İstanbul, 1959.

ALANGOYA, Yavuz, "Kanun Yolunun Anayasal Temeli ve HUMK m. 427 Hükmü ile Kanun Yolu Kapatılmış Olan Kararlara Karşı Kanun Yoluna Müracaat İmkanı”, Makaleler, Beta Yayınevi, İstanbul, 2012, (s. 219-248).

ALTAŞ, Hüseyin, Medeni Hukuk Başlangıç Hükümleri (TMK m. 1-7), Yetkin Yayınevi, Ankara, 2014.

ALTUĞ, Şahin, Ceza Hukukunda Müsadere Kavramı, Adalet Yayınevi, Ankara, 2017.

ASLAN, Kudret, Hacizde İstihkak Davası, Turhan Yayınevi, Ankara, 2005. (2005a)

ASLAN, Kudret, "Hacizde Sıra (Tertip)", Ankara Üniversitesi Hukuk Fakültesi Dergisi, Yı1: 2005, Cilt: 54, Say1: 2, (s. 269-318). (2005b)

ARSLAN, Ramazan, İcra-İflâs Hukukunda İhale ve İhalenin Feshi, Ankara Üniversitesi Hukuk Fakültesi Yayınları, Ankara, 1984.

ARTUK, Mehmet Emin/GÖKÇEN, Ahmet/YENIDÜNYA, Caner/ÇAKIR, Kerim, Ceza Hukuku (Genel Hükümler), 12. Bası, Adalet Yayınevi, Ankara, 2018.

BULUR, Alper, "İcra ve İflâs Hukukunda "Fesat Karıştırma" ve "Malın Esaslı Niteliklerinde Hata" ya Dayanan İhalenin Feshi Nedenleri”, Gazi Üniversitesi Hukuk Fakültesi Dergisi, Y11: 2017, Cilt: XI, Say1: 1-2, (s. 45-69).

CENTEL, Nur/ZAFER, Hamide/ÇAKMUT, Özlem, Türk Ceza Hukukuna Giriş, 10. Bası, Beta Yayınevi, İstanbul, 2017. 
DURSUN, İsmail, "Ceza Muhakemesi Hukukunda Taşınmazlara, Hak ve Alacaklara Elkoyma”,

Prof. Dr. Mehmet Akif Aydın'a Armağan, Ankara, 2015, (s. 535-558).

ERIŞSiR, Evrim, Geçici Hukukî Korumanın Türleri ve İhtiyatî Tedbir Türleri, On İki Levha Yayınevi, İstanbul, 2013.

ERTURGUT, Mine, İcra ve İflâs Hukukunda Menkullerin Paraya Çevrilmesi, Yetkin Yayınevi, Ankara, 2000.

GEDIK, Doğan, 5237 sayılı Türk Ceza Kanunu ve 5271 sayılı Ceza Muhakemesi Kanunu'na Göre Müsadere, 2. Bası, Adalet Yayınevi, Ankara, 2016.

GÖKCEN, Ahmet/BALCI, Murat/ALŞAHİN, Emin/ÇAKIR, Kerim, Ceza Muhakemesi Hukuku, 3. Bası, Seçkin Yayınevi, Ankara, 2018.

GÜNGÖR, Devrim/TOROSLU, Haluk, "Müsadere ve Hükmün Açıklanmasının Geri Bırakılması İlişkisi Üzerine Kısa Bir Değerlendirme”, Ankara Üniversitesi Hukuk Fakültesi Dergisi, Y11: 2016, Cilt: LXV, Say1: 4, (s. 1967-1980).

GÜNLER, Kemal, “Türk Ceza Hukukunda Müsadere”, Gazi Üniversitesi Hukuk Fakültesi Dergisi, Y11: 2014, C. XVIII, Say1: 3-4, (s. 849-876).

JEAN-RICHARD-dit-BRESSEL, Marc, "Konkorsprivileg durch Strafrecht?”, Schweizerische Zeitschrift für Zivilprozess- und Zwangsvollstreckungsrecht, Y11: 2017, Heft: 41, (s. 74-80).

KARAKAŞ, Cemal Fazıl, "Haciz Sıra Cetvelinin Şekli”, Prof. Dr. Saim Üstündağ’a Armağan, Seçkin Yayınevi, Ankara, 2009, (s. 295-310).

KÖKSOY, Mesut, İcra Hukukunda Hukuki Güvenlik İlkesi, Adalet Yayınevi, Ankara, 2018.

KURU, Baki/BUDAK, Ali Cem, Tespit Davaları, 2. Bası, On İki Levha Yayınevi, İstanbul, 2010.

KURU, Baki, İcra ve İflas Hukuku, 3. Bası, C. IV, Seçkin Yayınevi, Ankara, 1997.

KURU, Baki, İcra ve İflas Hukuku (El Kitabı), 2. Bası, Adalet Yayınevi, Ankara, 2013. 
MERIÇ, Nedim, Türk-İsviçre İcra Hukukunda Paylaştırma Kuralları ve Sıra Cetveline Müracaat Yolları, Yetkin Yayınevi, Ankara, 2015.

MUŞUL, Timuçin, İcra ve İflâs Hukuku, C. I, 6. Bası, Adalet Yayınevi, Ankara, 2013.

MUŞUL, Timuçin, İcra ve İflâs Hukukunda İhale ve İhalenin Feshi, Adalet Yayınevi, Ankara, 2016.

OĞUZMAN, Kemal/BARLAS, Nami, Medenî Hukuk (Giriş, Kaynaklar, Temel Kavramlar), 24. Bas1, Turhan Yayınevi, İstanbul, 2018.

ÖZEKES, Muhammet, İcra Hukukunda Temel Haklar ve İlkeler, Adalet Yayınevi, Ankara, 2009.

ÖZEKES, Muhammet, İcra ve İflâs Hukukunda İhtiyati Haciz, Seçkin Yayınevi, Ankara, 1999.

ÖZGENÇ, İzzet, Türk Ceza Hukuku, 14. Bası, Seçkin Yayınevi, Ankara, 2018.

ÖZMUMCU, Seda, Cebri İcra Hukukunda Pazarlık Suretiyle Satış, Vedat Yayınevi, İstanbul, 2005.

ÖZTÜRK, Bahri/ERDEM, Mustafa Ruhan, Uygulamalı Ceza Hukuku ve Güvenlik Tedbirleri Hukuku, 18. Bası, Seçkin Yayınevi, Ankara, 2018.

PEKCANITEZ, Hakan/ATALAY, Oğuz/SUNGURTEKİN-ÖZKAN, Meral/ÖZEKES, Muhammet, İcra İflâs Hukuku, 5. Bası, Vedat Yayınevi, İstanbul, 2018.

PEKCANITEZ, Hakan/ATALAY, Oğuz/ÖZEKES, Muhammet/ATALI, Murat/ERDÖNMEZ, Güray/Akkan, MİNE/YEŞILIRMAK, Ali/TAŞ KORKMAZ, Hülya: Medenî Usûl Hukuku, 15. Bası, C. II, İstanbul, 2017 (Anılış: Yazar, Pekcanıtez Usûl).

POSTACIOĞLU, İlhan E./ALTAY Sümer, İcra Hukuku Esasları, 5. Bası, Vedat Yayınevi, İstanbul, 2010.

SOYGÜT-ARSLAN, Mualla Buket, Türk Ceza Hukukunda Müsadere, Yayımlanmamış Doktora Tezi, İstanbul, Galatasaray Üniversitesi Sosyal Bilimler Enstitüsü, 2014.

ŞEN, Ersan/ERYILDIZ, Hüsnü Sefa, Elkoyma, Seçkin Yayınevi, İstanbul, 2017. 
TANRIVER, Süha, Medenî Usûl Hukuku (Temel Kavramlar ve İlk Derece Yargılaması), C. 1, 2. Bas1, Yetkin Yayınevi, Ankara, 2018.

ÜSTÜNDAĞ, Saim, İcra Hukukunun Esasları, 8. Bası, Yaylacık Matbaacılık, İstanbul, 2004.

von Heintschel-Heinegg, Bernd (Hrsg.): Beck'scher Online-Kommentar zum Strafgesetzbuch, 34. Ed., München, 2017 (Anılış: BeckOK StGB).

YAVAŞ, Murat, Borçlunun Üçüncü Şahıslardaki Mal, Hak ve Alacaklarının Haczi (İíK m. 89), Arıkan Yayınevi, İstanbul, 2005.

YENISEY, Feridun/NUHOĞLU, Ayşe, Ceza Muhakemesi Hukuku, 6. Bası, Seçkin Yayınevi, Ankara, 2018.

YILDIRIM, Mehmet Kâmil/DEREN-YILDIRIM, Nevhis, İcra ve İflas Hukuku, 7. Bası, Beta Yayınevi, İstanbul, 2016.

YILMAZ, Ejder, İcra ve İflâs Kanunu Şerhi, Yetkin Yayınevi, Ankara, 2016.

YILMAZ, Ejder, "Hacze Takipsiz Katılma (Hacze Adi İştirak)”, Ankara Üniversitesi Hukuk Fakültesi Dergisi, Y11: 1973, Cilt: 30, Say1: 1, (s. 271-316).

ZAFER, Hamide, Ceza Hukuku Genel Hükümler (TCK m. 1-75), 6. Bası, Beta Yayınevi, İstanbul, 2016. 